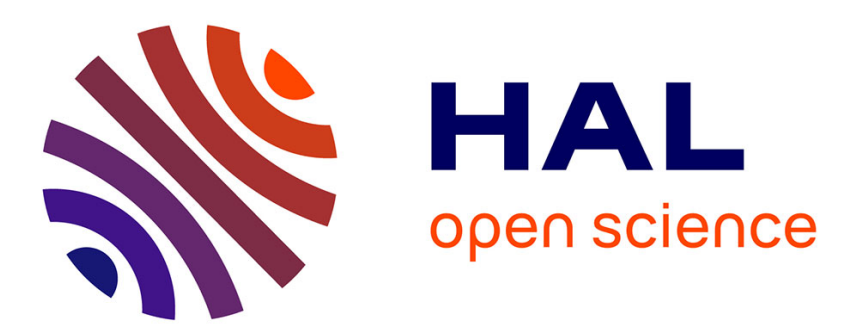

\title{
Divalent Mercury in Dissolved Organic Matter Is Bioavailable to Fish and Accumulates as Dithiolate and Tetrathiolate Complexes
}

Jean-Paul Bourdineaud, Maria Gonzalez-Rey, Mauro Rovezzi, Pieter Glatzel, Kathryn Nagy, Alain Manceau

\section{To cite this version:}

Jean-Paul Bourdineaud, Maria Gonzalez-Rey, Mauro Rovezzi, Pieter Glatzel, Kathryn Nagy, et al.. Divalent Mercury in Dissolved Organic Matter Is Bioavailable to Fish and Accumulates as Dithiolate and Tetrathiolate Complexes. Environmental Science and Technology, 2019, 53 (9), pp.4880-4891. 10.1021/acs.est.8b06579 . hal-02314781

\section{HAL Id: hal-02314781 \\ https://hal.science/hal-02314781}

Submitted on 13 Oct 2019

HAL is a multi-disciplinary open access archive for the deposit and dissemination of scientific research documents, whether they are published or not. The documents may come from teaching and research institutions in France or abroad, or from public or private research centers.
L'archive ouverte pluridisciplinaire HAL, est destinée au dépôt et à la diffusion de documents scientifiques de niveau recherche, publiés ou non, émanant des établissements d'enseignement et de recherche français ou étrangers, des laboratoires publics ou privés. 


\section{Divalent mercury in dissolved organic matter is bioavailable to fish and 2 accumulates as dithiolate and tetrathiolate complexes}

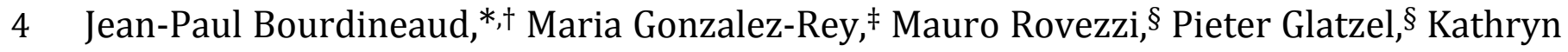

5 L. Nagy,"Alain Manceau*,o

6

7 †Institut Européen de Chimie et Biologie, Université de Bordeaux, CNRS, 2 rue Escarpit, 33607

8 Pessac, France

$9 \quad \ddagger$ Laboratoire EPOC, Université de Bordeaux, CNRS, 33120 Arcachon, France.

10 §European Synchrotron Radiation Facility (ESRF), 71 Rue des Martyrs, 38000 Grenoble, France

11 "Department of Earth and Environmental Sciences, University of Illinois at Chicago, MC-186, 845

12 West Taylor Street, Chicago, Illinois 60607, United States

$13{ }^{\infty}$ ISTerre, Université Grenoble Alpes, CNRS, 38000 Grenoble, France

$15 *$ Corresponding Authors :

16 E-mail: jean-paul.bourdineaud@u-bordeaux.fr

17 E-mail: alain.manceau@univ-grenoble-alpes.fr. Phone: +334 76635193.

19 Keywords: Mercury, fish, DOM, speciation, metacinnabar, XANES 


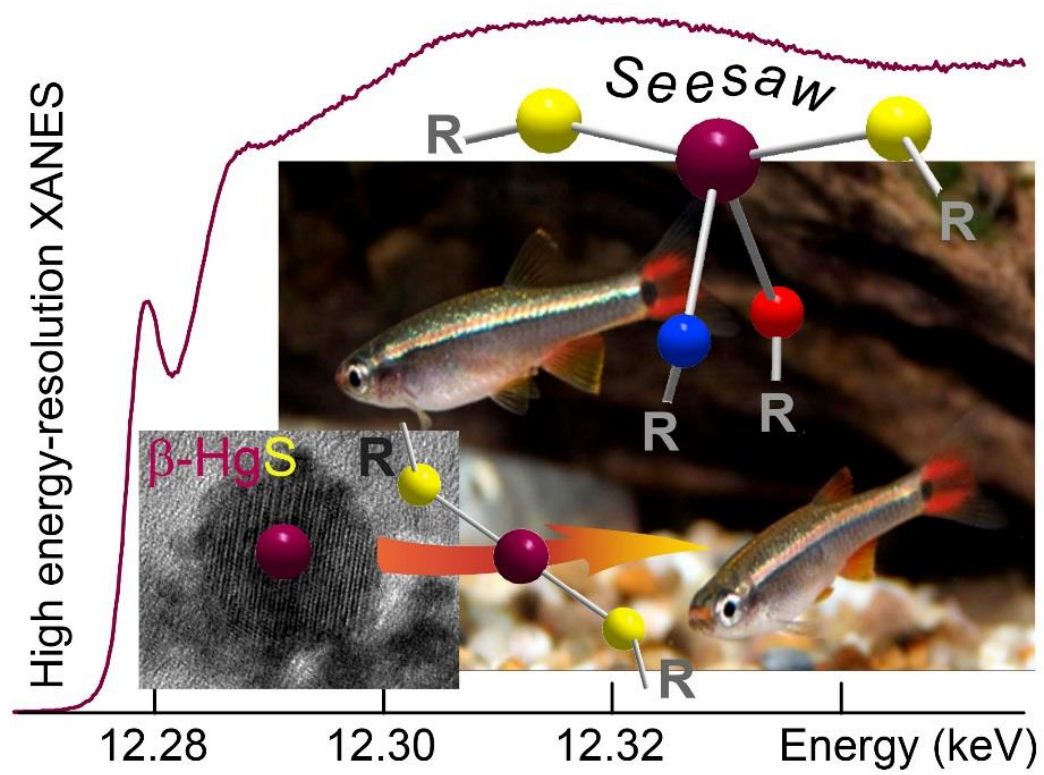

\section{ABSTRACT}

The freshwater cyprinid Tanichthys albonubes was used to assess the bioavailability of

24 divalent mercury (Hg(II)) complexed in dissolved organic matter (DOM) to fish. The fish acquired

250.3 to $2.2 \mu \mathrm{g} \mathrm{Hg} / \mathrm{g}$ dry weight after eight weeks in aquaria containing DOM from a Carex peat with

26 complexed mercury at initial concentrations of $14 \mathrm{nM}$ to $724 \mathrm{nM}$. Changes in the relative

27 proportions of dithiolate $\mathrm{Hg}(\mathrm{SR})_{2}$ and nanoparticulate $\beta-\mathrm{HgS}$ in the $\mathrm{DOM}$, as quantified by high

28 energy-resolution XANES (HR-XANES) spectroscopy, indicate that $\mathrm{Hg}(\mathrm{SR})_{2}$ complexes either

29 produced by microbially-induced dissolution of nanoparticulate $\beta$ - $\mathrm{HgS}$ in the DOM or present in

30 the original DOM were the forms of mercury that entered the fish. In the fish with $2.2 \mu \mathrm{g} \mathrm{Hg} / \mathrm{g}, 84$

$31 \pm 8 \%$ of $\mathrm{Hg}(\mathrm{II})$ was bonded to two axial thiolate ligands and one or two equatorial $\mathrm{N} / \mathrm{O}$ electron

32 donors $\left(\mathrm{Hg}\left[(\mathrm{SR})_{2}+(\mathrm{N} / 0)_{1-2}\right]\right.$ coordination $)$, and $16 \%$ had a $\mathrm{Hg}(\mathrm{SR})_{4}$ coordination, as determined

33 by HR-XANES. For comparison, fish exposed to $\mathrm{Hg}^{2+}$ from $40 \mathrm{nM} \mathrm{HgCl}_{2}$ contained $10.4 \mu \mathrm{g} \mathrm{Hg} / \mathrm{g}$ in

34 the forms of dithiolate $(20 \pm 10 \%)$ and tetrathiolate $(23 \pm 10 \%)$ complexes, and also $\mathrm{Hg}_{\mathrm{x}} \mathrm{S}_{\mathrm{y}}$ clusters

35 (57 $\pm 15 \%)$ having a $\beta$-HgS-type local structure and a dimension that exceeded the size of

36 metallothionein clusters. There was no evidence of methylmercury in the fish or DOM within the

$3710 \%$ uncertainty of the HR-XANES. Together, the results indicate that inorganic $\mathrm{Hg}(\mathrm{II})$ bound to 
DOM is a source of mercury to biota with dithiolate $\mathrm{Hg}(\mathrm{SR})_{2}$ complexes as the immediate species

39 bioavailable to fish, and that these complexes transform in response to cellular processes.

\section{INTRODUCTION}

42 Mercury $(\mathrm{Hg})$ is a potent neurotoxin in animals and humans that bioaccumulates in aquatic

43 food webs mainly as organic methylmercury (MeHg). Although dietary ingestion of MeHg is the

44 primary exposure pathway in fish, exposure also occurs by intake of waterborne forms of MeHg

45 and inorganic (Hg(II)) mercury, both of which can rapidly contaminate an entire ecosystem. Field

46 and laboratory experiments showed that $10 \%$ to $38 \%$ of total mercury accumulated in fish can

47 originate directly from water. ${ }^{1-6}$ The relative importance of the food and water entryways may be

48 seasonal, with a water source dominating in the spring and fall, for example reaching up to $80 \%$

49 of the total MeHg accumulated in yellow perch (Perca flavescens), and a food source dominating

50 in the summer. ${ }^{7}$ In previous experiments conducted with free ionic mercury species $\left(\mathrm{MeHg}^{+}\right.$,

$51 \mathrm{Hg}^{2+}$ ), mercury was considered to enter fish tissues through gills. However, mercury is strongly

52 bound to dissolved organic matter (DOM) in aquatic systems, ${ }^{8}$ and therefore may not be readily

53 available for respiratory uptake. Mercury was less bioavailable to fish and zooplankton in the field

54 and in laboratory experiments when complexed to DOM.9-22 Similarly, complexation to DOM has

55 also been shown to reduce the toxicity of $\mathrm{Zn}$ to rainbow trout ${ }^{9}$ and the toxicity of both $\mathrm{Zn}$ and $\mathrm{Cd}$

56 to the microalga Pseudokirchneriella subcapitata. ${ }^{23}$

57 In contrast, other studies have reported that $\mathrm{Hg}$ concentration in fish increases with the

58 amount of dissolved organic carbon (DOC). ${ }^{13,24-29}$ In aquatic invertebrates from Arctic tundra

59 lakes, mercury bioaccumulation was promoted at [DOC] $<8.8 \mathrm{mg} \mathrm{C} / \mathrm{L}$, but inhibited above this

60 concentration. ${ }^{30}$ Bioaccumulation, toxicity, and uptake level of $\mathrm{Cd}$ by aquatic organisms all have

61 been shown to increase in the presence of DOM in freshwater and seawater.9, 31-33 Lastly, under 
62 anaerobic conditions, Desulfovibrio desulfuricans bacteria were able to methylate $\mathrm{Hg}$ complexed

63 to $\mathrm{DOM}^{34}$ indicating that at least some of the complexed $\mathrm{Hg}$ is easily bioavailable.

64 The molecular structure of any metal cation in the DOM must play a principal role in the 65 processes that lead to bioavailability. Inorganic Hg in DOM occurs in two dominant forms: a linear 66 dithiolate complex $\left(\mathrm{Hg}(\mathrm{SR})_{2}\right)$ and nanoparticulate metacinnabar $\left(\beta-\mathrm{HgS}_{\mathrm{NP}}\right) \cdot 35-37$ These forms may 67 be altered under oxygenated biotic conditions, for example as a result of the microbial production 68 of extracellular low-molecular-weight (LMW) thiols that might extract $\mathrm{Hg}$ from the larger 69 molecules of DOM.38

70 The forms of inorganic Hg in DOM that are bioavailable to fish were assessed by exposing

71 Tanichthys albonubes, which belongs to the Cyprinidae family like Denio rerio (zebrafish), to DOM

72 pre-equilibrated with $\mathrm{Hg}(\mathrm{II})$ in aquaria. After eight weeks, the molecular structures of $\mathrm{Hg}$ in the

73 DOM and fish were determined by high energy-resolution X-ray absorption near-edge structure

74 (HR-XANES) spectroscopy. 37,39 The initial concentration of DOM was fixed to $29.6 \mathrm{mg} \mathrm{C} / \mathrm{L}$, and

75 the Hg concentration in the initial DOM was varied from 28 to $1453 \mu \mathrm{g} \mathrm{Hg} / \mathrm{g}$ dry DOM producing

7614 to $724 \mathrm{nM} \mathrm{Hg}(\mathrm{II})$ in the aquaria. For comparison, dissolved organic carbon (DOC)

77 concentrations range from 10 to $80 \mathrm{mg} / \mathrm{L}$ in peatland pore waters from North America, ${ }^{40}$ and

78 from 60 to $200 \mathrm{mg} / \mathrm{L}$ in coastal lagoons in Rio de Janeiro State, Brazil. ${ }^{41}, 42$ The mercury

79 concentrations are representative of contaminated water, beginning just above the $10 \mathrm{nM}$

80 maximum contaminant level (MCL) for inorganic mercury in primary drinking water. ${ }^{43}$ Changes

81 from the initial $\beta-\mathrm{HgS}_{\mathrm{NP}}: \mathrm{Hg}(\mathrm{SR})_{2}$ ratio in the DOM and characterization of the molecular structure

82 of mercury in the fish would indicate processes that may release Hg from the DOM, making it

83 bioavailable. The forms of mercury in the fish potentially could be biomarkers of exposure to

84 inorganic mercury sourced from DOM in aquatic systems. 
MATERIALS AND METHODS

87 A detailed description of the experimental and computational methods is given in the Supporting 88 Information (SI).

Preparation of Hg-DOM. The DOM was extracted from a Carex peat. ${ }^{44,45}$ Divalent mercury was added at pH 6 to obtain initial concentrations of 28, 270, and $1453 \mu \mathrm{g} \mathrm{Hg} / \mathrm{g}$ dry DOM

91 (hereafter called $\mathrm{DOM}_{\mathrm{i}}-28, \mathrm{DOM}_{\mathrm{i}}-270$ and $\mathrm{DOM}_{\mathrm{i}}-1453$ ), and the Hg-DOM solutions were aged in

92 the dark for six months following the protocol described previously for $\mathrm{Hg}$ (II) complexed to Elliott

93 Soil humic acid. ${ }^{37}$

94 Fish exposure to $\mathbf{H g ( I I ) - D O M}$ and dissolved $\mathbf{H g C l}_{2}$. Fifty-five adult T. albonubes were 95 placed in each of 12 separate aquaria containing aerated chlorine-free water at pH $7.7 \pm 0.05$ and 96 maintained at $21 \pm 4{ }^{\circ} \mathrm{C}$, and six experimental conditions were replicated. Three were controls:

$97 \mathrm{C}_{0}$, without DOM and without $\mathrm{Hg}(\mathrm{II})$; $\mathrm{C}_{\mathrm{DOM}}$, with DOM and without $\mathrm{Hg}(\mathrm{II})$; and $\mathrm{C}_{\mathrm{Hg}}$, without DOM 98 and with $8 \mu \mathrm{g} / \mathrm{L} \mathrm{Hg}^{2+}$ (40 nM Hg) from a $\mathrm{HgCl}_{2}$ stock solution (> 99.5\% purity, Merck). For the 99 other three, the stock Hg-DOM suspensions containing $570 \mathrm{mg}$ DOM/L were diluted in the aquaria 100 to a final concentration of $100 \mathrm{mg}$ DOM/L, or $29.6 \mathrm{mg}$ DOC/L yielding calculated initial $\mathrm{Hg}$ 101 concentrations of $14 \mathrm{nM}$ or $2.8 \mu \mathrm{g} / \mathrm{L}\left(\mathrm{DOM}_{\mathrm{i}}-28\right), 135 \mathrm{nM}$ or $27 \mu \mathrm{g} / \mathrm{L}\left(\mathrm{DOM}_{\mathrm{i}}-270\right)$, and $724 \mathrm{nM}$ or $102145 \mu \mathrm{g} / \mathrm{L}(\mathrm{DOM}-1453) .{ }^{46}$ Total Hg concentrations were measured in water $(n=4,2$ per duplicated 103 aquarium) at the start of the experiment $\left(t_{0}\right)$ and after one $\left(t_{1}\right)$, two $\left(t_{2}\right)$, four ( $\left.t_{4}\right)$, and eight ( $\left.t_{8}\right)$ 104 weeks ( $\left.t_{8}\right)$ for all aquaria and in whole fish $\left(n=6,3\right.$ per duplicated aquarium) at $t_{1}, t_{2}, t_{4}$ and $t_{8}$ 105 for all aquaria except Co. Mercury concentration was determined in six fish at to from the 106 acclimatization tank. After eight weeks, whole fish from the DOM $\mathrm{M}_{\mathrm{i}}-1453$ and $\mathrm{C}_{\mathrm{Hg}}$ experiments 107 were lyophilized and analyzed by HR-XANES spectroscopy. Freeze-drying a frozen tissue does not 108 change the speciation of the metal. ${ }^{47,} 48$ The possibility of methylation in the Hg-DOM experiments 
was tested by comparison to a separate experiment in which fish were exposed to $\mathrm{MeHg}\left(\mathrm{C}_{\mathrm{MeHg}}\right)$,

110 as described previously. 49

111 Hg Analyses. Mercury in fish was quantified with an AMA-254 mercury analyzer (Altec,

112 Prague) (fish) and in DOM with a DMA-80 (Milestone, Dual-Cell).

113 HR-XANES spectroscopy. Mercury L3-edge HR-XANES spectra were measured at 10-15 K

114 with high-reflectivity analyzer crystals ${ }^{50}$ on beamline ID26 at the European Synchrotron

115 Radiation Facility (ESRF). Data were analyzed against a large database of spectra for mercury

116 minerals $\left(\alpha-\mathrm{HgS}, \beta-\mathrm{HgS}, \beta-\mathrm{HgS}_{\mathrm{NP}}\right.$ ), $\mathrm{Hg}(\mathrm{II})$ complexes in natural organic matter, and $\mathrm{Hg}(\mathrm{II})$ and

117 methylmercury (MeHg) model complexes with thiolate ligands. $36,37,39,51,52$. All reference spectra

118 were considered as a basis for identification, but only diagnostic spectra are discussed herein.

119 Geometry optimization of model Hg complexes. The geometries of structural models for

120 the Hg complexes were optimized at a high level of molecular orbital theory (MP2/TZVP-ecp)

121 using ORCA 3.0.353 and a computational scheme tested previously on the modeling of the

122 structure and stability of monomeric Hg-thiolate complexes, ${ }^{36,37,54}$ and herein on the

123 Hg(Cysteamine)2 complex (Figure S1).

\section{RESULTS}

126 Transfer of Hg(II) from DOM to fish. Chemical analyses of fish tissue show that $\mathrm{Hg}$ (II)

127 initially bound to DOM became bioavailable (Table 1). Whole fish exposed to initial [HgDom] of 2.8,

12827 , and $145 \mu \mathrm{g} / \mathrm{L}$ (14 to $724 \mathrm{nM}$ ) contained corresponding amounts of $0.33,1.06$, and $2.20 \mu \mathrm{g}$

$129 \mathrm{Hg} / \mathrm{g}$ dry weight fish after eight weeks. Fish in the control $\mathrm{C}_{0}$ aquaria with neither Hg nor DOM

130 contained $0.022 \pm 0.007 \mu \mathrm{g} \mathrm{Hg} / \mathrm{g}$ wet weight $(0.09 \pm 0.03 \mu \mathrm{g} \mathrm{Hg} / \mathrm{g}$ dry weight). The amounts of

131 mercury in the fish after eight weeks corrected for the amount in the control fish $\left(\mathrm{C}_{0}\right)$ were 1.9,

1320.88 , and $0.32 \%$, respectively, of the total final mass of Hg present in aquaria in both water and 
133 fish. The fraction of $\mathrm{Hg}(\mathrm{II})$ transferred to fish was much higher in the $\mathrm{C}_{\mathrm{Hg}}$ aquaria with initial

$134\left[\mathrm{HgCl}_{2}\right]$ of $8 \mu \mathrm{g} / \mathrm{L}(40 \mathrm{nM})$, reaching 50\% after eight weeks (Table S1). Total Hg in whole fish

135 exposed to $\mathrm{Hg}$-DOM ranged from 3 to $21 \%$ of the amount in fish in the $\mathrm{C}_{\mathrm{Hg}}$ experiment with $\mathrm{HgCl}_{2}$

136 (10.4 $\mu \mathrm{g} \mathrm{Hg} / \mathrm{g}$ fish) and was 3 to 24 times higher than the amount in the control $\mathrm{C}_{0}$ experiment.

137 Although the transfer percentages in the Hg-DOM experiments are low, they confirm that this pool

138 of mercury can become bioavailable.

139 A higher percentage of $\mathrm{Hg}$ was bioavailable from DOM that contained lower amounts of Hg

140 (Table 1). Conservative values for bioconcentration factors (BCFs), defined as the ratio of the

141 chemical concentration in the fish (on a wet weight basis) to the initial concentration in water,

142 were 27 in the $\left[\mathrm{Hg}_{\text {Dом }}\right]=2.8 \mu \mathrm{g} / \mathrm{L}$ experiment and decreased to 8.3 and 4.4 in the $\left[\mathrm{Hg}_{\text {DOM }}\right]=27$

143 and $145 \mu \mathrm{g} / \mathrm{L}$ experiments, respectively. These BCFs follow the expected ecotoxicological rule for

144 pollutant uptake by organisms (Table S2).

$145 \quad$ After eight weeks, the concentration of $\mathrm{Hg}$ in the DOM decreased from 28 to $2 \mu \mathrm{g} / \mathrm{g}$ (DOM $\mathrm{i}^{-}$

$\left.14628, \mathrm{DOM}_{\mathrm{f}}-2\right), 270$ to $27 \mu \mathrm{g} / \mathrm{g}\left(\mathrm{DOM}_{\mathrm{i}}-270, \mathrm{DOM}_{\mathrm{f}}-27\right)$, and 1453 to $240 \mu \mathrm{g} / \mathrm{g}\left(\mathrm{DOM}_{\mathrm{i}}-1453, \mathrm{DOM} \mathrm{f}-240\right)$

147 (Table 1). Given that the amounts of $\mathrm{Hg}$ acquired by the fish were relatively small compared to

148 the system totals, these large changes resulted from both an increase in the quantity of DOM over

149 time, from food addition and production of biogenic DOM in the aquaria, and from loss of the

150 initial DOM and its associated Hg to the filtration apparatus (SI and Table S3). Neither change in

151 the amount of DOM in the systems was quantified.

152 Changes in proportions of molecular structures of $\mathbf{H g}$ in DOM. The initial $\beta$ -

$153 \mathrm{HgS}_{\mathrm{NP}}: \mathrm{Hg}(\mathrm{SR})_{2}$ ratio in the $\left[\mathrm{Hg}_{\mathrm{DOM}}\right]=2.8 \mu \mathrm{g} / \mathrm{L}$ experiment $\left(\mathrm{DOM}_{\mathrm{i}}-28\right)$ decreased considerably after

154 eight weeks (DOM $\mathrm{M}_{\mathrm{f}}$ 2) (Figure 1a). The DOMi-28 spectrum was modeled as a linear combination

155 of $88 \% \beta-\mathrm{HgS}_{\mathrm{NP}}$ and $12 \% \mathrm{Hg}(\mathrm{SR})_{2}( \pm 8$ at. $\%)$ compared to $37 \% \beta-\mathrm{HgS}_{\mathrm{NP}}$ and $63 \% \mathrm{Hg}(\mathrm{SR})_{2}( \pm 10$

156 at. \%) in $\mathrm{DOM}_{\mathrm{f}}-2$ (Figures $1 \mathrm{~b}$ and $1 \mathrm{c}$ and Table S4). This result suggests that nanoparticulate $\beta$ - 
$157 \mathrm{HgS}$ in $\mathrm{DOM}_{\mathrm{i}}-28$ was the main source of the Hg that became bioavailable, and also that new

$158 \mathrm{Hg}(\mathrm{SR})_{2}$ complexes may have been generated from the $\beta$-HgS. To demonstrate that the shift in

159 species proportions required the presence of living organisms, the DOMi-28 stock solution was

160 diluted to the same concentration as in the fish aquaria, and aged at ambient temperature in air-

161 equilibrated water for eight weeks, in the presence or absence of light. Spectra for these samples

162 were similar to each other and to that of the original DOM $\mathrm{i}_{\mathrm{i}} 28$ (Figure S2a) showing that the

163 change in $\beta$-HgS: $\mathrm{Hg}(\mathrm{SR})_{2}$ ratio was related to the presence of the fish.

164 In contrast to $\mathrm{DOM}_{\mathrm{f}}-2$, the changes in the ratio of $\beta-\mathrm{HgS}_{\mathrm{NP}}$ to $\mathrm{Hg}(\mathrm{SR})_{2}$ were smaller in $\mathrm{DOM} \mathrm{f}^{-}$

16527 and DOMf-240 compared to the initial values (Figure S3) despite the observation that fish 166 accumulated three times (DOM $\left.\mathrm{f}_{\mathrm{f}}-27\right)$ and seven times (DOMf-240) as much $\mathrm{Hg}$ as in the DOMf-2

167 experiment (Table 1). The smaller variations in these ratios are directly related to the lower 168 proportions of $\mathrm{Hg}$ transferred to fish (0.88 and $0.32 \%$, respectively, of the $\mathrm{Hg}$ at $\left.\mathrm{t}_{8}\right)$.

169 Form of Hg in fish from Hg-DOM experiments. Fish from the DOMi-1453 experiment were 170 examined by HR-XANES because the concentration of $\mathrm{Hg}$ was above the detection limit of $0.5 \mu \mathrm{g}$

$171 \mathrm{Hg} / \mathrm{g}^{39}$ (Table 1). The spectrum (Fish-DOM) is distinct from those of the initial (DOMi-1453) and 172 final (DOMf-240) DOM samples, and from those of fish contaminated with MeHg (Fish-MeHg from 173 the $\mathrm{C}_{\mathrm{MeHg}}$ experiment) and $\mathrm{Hg}^{2+}$ (Fish-Hg from the $\mathrm{C}_{\mathrm{Hg}}$ experiment) (Figures $2 \mathrm{a}$ and $2 \mathrm{~b}$ ). Also, the 174 molecular structure of $\mathrm{Hg}$ in Fish-DOM is not a simple mixture of the structures in fish exposed to $175 \mathrm{MeHg}$ and $\mathrm{HgCl}_{2}$ (Figure 2c).

176 The Fish-DOM spectrum was most similar to those for $\mathrm{Hg}(\mathrm{II})$ complexed to L-glutathione $177(\mathrm{Hg}(\mathrm{GSH}) 2$, with $\mathrm{GSH}=\gamma$-Glu-Cys-Gly) and to L-cysteine ( $\mathrm{Hg}(\mathrm{Cys}) 2)$ at pH 7.5 from the spectral 178 database $36,37,39,51$ (Figure 3a). Two component fits of $\mathrm{Hg}(\mathrm{GSH})_{2}$ or $\mathrm{Hg}(\mathrm{Cys})_{2}$ with $\mathrm{Hg}(\mathrm{Cys})_{4}$ 179 decreased the fit residuals (NSS) (Figure 3b) and both fits match the normalized X-ray absorption 180 to within about $2 \%$ (Figure 3c). The species proportions are $88 \% \mathrm{Hg}(\mathrm{GSH})_{2}+12 \% \mathrm{Hg}(\mathrm{Cys})_{4}$ or 
$18180 \% \mathrm{Hg}(\text { Cys })_{2}+20 \% \mathrm{Hg}$ (Cys) 4 with uncertainties of $\pm 8 \%$. Therefore, on average about $84 \%$ of

182 the $\mathrm{Hg}$ in fish is two-coordinate $\left(\mathrm{Hg}(\mathrm{SR})_{2}\right)$ and $16 \%$ is four-coordinate $(\mathrm{Hg}(\mathrm{SR}) 4)$.

183 The molecular structure of $\mathrm{Hg}$ in the fish is discerned by considering how glutathione and

184 cysteine bond to $\mathrm{Hg}$ according to geometry optimization by $a b$ initio post-Hartree-Fock 185 computations. ${ }^{36,54}$ In $\mathrm{Hg}(\mathrm{GSH})_{2}, \mathrm{Hg}(\mathrm{II})$ is bonded approximately linearly to the cysteinyl sulfur

186 atoms at $2.33 \AA$ A from the two $\gamma$-Glu-Cys-Gly peptides and surrounded in trans-equatorial position

187 by a carboxyl oxygen from a Gly residue at $2.62 \AA$, the backbone carbonyl oxygen at $2.88 \AA$ from

188 the Gly-Cys peptide bond (Gly-NH-CO-Cys) of the same GSH molecule, and an amide group (-NH)

189 at $3.01 \AA$ from the second GSH molecule (Figure 4a and Video S1). The shorter Hg-O distance is

190 well below the sum of the van der Waals radii of $3.07 \AA$ for the Hg-O pair, whereas the longer Hg-

1910 distance approaches it, and the Hg-N distance is close to the value of $3.10 \AA$ A for the Hg-N pair.

192 The two $\mathrm{O}$ atoms are close enough to $\mathrm{Hg}$ to be considered secondary bonding interactions, but the

$193 \mathrm{~N}$ atom is not. The complex is a double-ring chelate with one ring of six members and the other

194 seven. The coordination of $\mathrm{Hg}$ is $\mathrm{Hg}\left[(\mathrm{SR})_{2}+\mathrm{O}_{2}\right]$, and the geometry is disphenoidal, or seesaw (i.e.,

195 an octahedron without two cis-equatorial ligands). ${ }^{5}$ The S-Hg-S angle is bent to $167.2^{\circ}$ by the

196 carboxyl oxygen (Figures 4a), which on the HR-XANES spectrum is seen as a decrease in the near-

197 edge peak intensity (Figures S4 and S5a).

198 The structure of the $\mathrm{Hg}(\mathrm{Cys})_{2}$ complex depends on $\mathrm{pH}$, which changes the protonation of the 199 amine groups. The structure ranges from a nearly linear $\mathrm{Hg}(\mathrm{SR})_{2}$ coordination with weak $\mathrm{Hg}-\mathrm{OOC}$ 200 contacts at 3.06-3.15 $\AA$ at $\mathrm{pH} 3\left(\mathrm{Hg}(\mathrm{SR})_{2}\right.$ coordination) to a bis five-membered ring chelate (Hg[5$201 \mathrm{~S} / \mathrm{N}-$ ring]2) with $\mathrm{Hg}$ coordination of $\mathrm{Hg}\left(\mathrm{SR}+\mathrm{NH}_{2}\right)_{2}$ and disphenoidal geometry, like when bonded 202 to GSH, at pH 11.5 (Figure S4). However, it is unlikely that both amine groups deprotonate and 203 fold simultaneously to form a double-ring chelate, ${ }^{39}, 55-57$ and therefore at $\mathrm{pH} 7.5$, near 204 physiological conditions, the $\mathrm{Hg}$ coordination is most likely dominantly $\mathrm{Hg}\left[(\mathrm{SR})_{2}+\mathrm{NH}_{2}\right]$. The 
structure of $\mathrm{Hg}(\mathrm{GSH})_{2}$, which is bent by a carboxyl oxygen, and the structure of $\mathrm{Hg}(\mathrm{Cys})_{2}$, which

206 is bent by an amine group, give nearly identical HR-XANES traces (Figure S5a). We conclude that

207 Hg is bonded in the Fish-DOM dithiolate complex to two cysteinyl sulfur atoms and to one or two

208 nucleophilic donors, such as amine and amide nitrogen and carboxyl and carbonyl oxygen. The

209 dithiolate $\mathrm{Hg}$ coordination in fish is denoted $\mathrm{Hg}\left[(\mathrm{SR})_{2}+(\mathrm{N} / \mathrm{O})_{1-2}\right]$.

210 The $\mathrm{Hg}(\mathrm{Cys})_{4}$ complex, synthesized at $\mathrm{pH} 11.9$, has four thiolate ligands at $2.52 \AA \AA^{51}$ a distance

$211 \sim 0.17 \AA$ longer than that in $\mathrm{Hg}(\mathrm{Cys})_{2}$. In HR-XANES, the post-edge absorption shifts to lower

212 energy because of the increase in bond length in agreement with the Natoli rule ${ }^{58}$ and, the near-

213 edge peak disappears because of the tetrahedral coordination. Both features occur in the Fish-

214 DOM spectrum. Although $\beta$-HgSNP also has four-coordinate $\mathrm{Hg}(\mathrm{II})$, and therefore these same

215 spectral features, there is no modulation at $12300 \mathrm{eV}$ and above in the Fish-DOM spectrum

216 indicative of the $\mathrm{Hg}$-Hg pairs in $\beta$-HgS $\mathrm{NP}$ (Figures 1 and S2). Thus, $\mathrm{Hg}(\mathrm{Cys}) 4$, with coordination

217 denoted $\mathrm{Hg}(\mathrm{SR})_{4}$, is considered a good representation of the tetrahedral coordination of $\mathrm{Hg}$ in 218 fish.

219 Form of $\mathbf{H g}$ in fish from the $\mathbf{H g}(\mathbf{C l})_{2}$ experiment. The Fish-Hg spectrum has features like

220 those of $\beta$-HgS $\mathrm{NP}$ including a bumpy profile at high energy indicative of $\mathrm{Hg}$-Hg pairs (Figure S6a).

221 Linear least-squares fits identified $\beta-\mathrm{HgS}_{\mathrm{NP}}$ as the first component, $\mathrm{Hg}(\mathrm{Cys})_{4}$ as the second and

$222 \mathrm{Hg}(\mathrm{Cys})_{2}$ at $\mathrm{pH} 7.5$ as the third, immediately followed by $\mathrm{Hg}(\mathrm{GSH})_{2}$ (Figure S6a). A two-component

223 fit with $83 \% \beta-\mathrm{HgS}_{\mathrm{NP}}+17 \% \mathrm{Hg}(\mathrm{Cys})_{4}$ decreased $\mathrm{NSS}$ by $35 \%$ compared to the $\beta-\mathrm{HgS}_{\mathrm{NP}}$ fit, and a

224 three-component fit with $57 \pm 15 \% \beta-\mathrm{HgS}_{\mathrm{NP}}+23 \pm 10 \% \mathrm{Hg}(\mathrm{Cys})_{4}+20 \pm 10 \% \mathrm{Hg}(\mathrm{Cys})_{2}$ pH 7.5

225 decreased NSS by an additional 51\%. Replacing $\mathrm{Hg}(\mathrm{Cys})_{2}$ with $\mathrm{Hg}(\mathrm{GSH})_{2}$ reduced NSS by an

226 additional 49\%, confirming that the two model complexes are indistinguishable. Both three-

227 component best-fit residuals are as low as 1\% (Figure S6b). 
Form of $\mathrm{Hg}$ in fish from the methylmercury experiment. The spectrum for $\mathrm{MeHg}$

229 complexed to L-cysteine at $\mathrm{pH} 7.5$ provided the best match to the Fish-MeHg spectrum, as 230 expected $^{59}$ (Figure S7a). HR-XANES spectra of the MeHgCys complex as a function of pH and

231 corresponding geometry optimizations show that the amine group is folded at $\mathrm{pH} \geq 4.5$ to form

232 an aminothiolate ring chelate as in $\mathrm{Hg}(\mathrm{Cys})_{2}$, except that the complex is a mono-cysteinate

$233\left(\mathrm{MeHg}\left(\mathrm{SR}+\mathrm{NH}_{2}\right)\right.$ coordination) (Figures S4e and S7). In comparison, the spectrum of MeHg

234 complexed to DOM (Nordic Aquatic fulvic acid: NAFA-MeHg) has a deeper near-edge minimum

235 and is shifted to the right in the range 12282-12286 eV (Figure S7b). Like in the comparison of

236 Fish-DOM and pH $3 \mathrm{Hg}(\mathrm{Cys}) 2$ spectra (Figure S5a), and the evolution of the MeHgCys spectra with

$237 \mathrm{pH}$ (Figure S4d), this shift results from the lack of secondary N/O ligands in NAFA-MeHg. Thus,

238 secondary coordination to N/O ligands, which occurs in Fish-MeHg, offers a means to differentiate

239 a dithiolate complex in living $\left(\mathrm{Hg}\left[(\mathrm{SR})_{2}+(\mathrm{N} / \mathrm{O})_{1-2}\right]\right.$ coordination) and detrital $\left(\mathrm{Hg}\left[(\mathrm{SR})_{2}\right.\right.$

240 coordination) organic matter. ${ }^{51}$

241 In the $\mathrm{C}_{\mathrm{MeHg}}$ experiment, no differences were observed within experimental noise of the HR-

242 XANES measurements between spectra from gills, brain, liver and muscle, indicating that the

243 binding environment is $\mathrm{MeHg}(\mathrm{SR}+\mathrm{N} / \mathrm{O})$ in all tissues, and that no demethylation occurred during

244 the 28 days of experiment, even in liver ${ }^{60-65}$ (Figure S7c). Thus, lack of an intense near-edge peak

245 in Fish-DOM and Fish-Hg is direct evidence that these fish did not contain detectable

246 methylmercury, implying that little to no MeHg formed in the DOM or biofilms in the oxygenated

247 aquaria.

248

249 DISCUSSION

250 Experimental parameters and the environment. The initial DOM concentrations in the

251 experiments are characteristic of natural aquatic environments, and the initial Hg concentrations 
252 represent environments contaminated with point sources of mercury. In natural waters away

253 from point sources, the concentration of dissolved $\mathrm{Hg}$ is between 0.2 and $15 \mathrm{ng} / \mathrm{L}$, and most often

254 below $5 \mathrm{ng} / \mathrm{L}{ }^{40,66}$ The experimental Hg concentration ranged from 2.8 to $145 \mu \mathrm{g} / \mathrm{L}$, starting just

255 above $2 \mu \mathrm{g} / \mathrm{L}$ which is the MCL for $\mathrm{Hg}$ in primary drinking water. With these higher initial 256 concentrations of $\mathrm{Hg}$ in the aquaria and the eight-week experimental duration, fish obtained

257 enough Hg for HR-XANES spectral acquisition within a reasonable timeframe. For example, the 258 good quality Fish-DOM spectrum was obtained in only 6 hours using high-reflectivity analyzer 259 crystals $^{48}$ on fish that acquired $2.1 \mu \mathrm{g} \mathrm{Hg} / \mathrm{g}(2.1 \mathrm{ppm} \mathrm{Hg})$ in the DOMi-1453 experiment.

260 The amounts of mercury in the fish from the Hg-DOM experiments ( 0.33 to $2.1 \mu \mathrm{g} \mathrm{Hg} / \mathrm{g}$ ),

261 bracket the amount of about $1 \mu \mathrm{g} / \mathrm{g}$ observed in wild fish from impacted areas ${ }^{66-68}$ that acquire

262 mercury over much longer periods. Despite a higher Hg/C ratio in the Hg-DOM experiments (94

263 to $4900 \mu \mathrm{g} \mathrm{Hg} / \mathrm{g} \mathrm{C}$ ) than is typical of the natural uncontaminated environment (0.006 to $0.5 \mu \mathrm{g}$

$264 \mathrm{Hg} / \mathrm{g} \mathrm{C}$ calculated with the experimental concentration of DOC), the mass fractions of total $\mathrm{Hg}$

265 transferred to the fish are in excellent agreement with results of similar experiments performed

266 with midge larvae in which the $\mathrm{Hg}$ concentration was $0.1 \mu \mathrm{g} / \mathrm{L}$ and $\mathrm{Hg} / \mathrm{C}$ ratios $(0.1$ to $1 \mu \mathrm{g} \mathrm{Hg} / \mathrm{g}$

267 C) overlapped the natural range. The mass fraction of total $\mathrm{Hg}$ transferred to fish was $21 \%$ in the

$268 \mathrm{HgCl}_{2}$ experiment and $0.33 \%$ to $2.1 \%$ in the $\mathrm{Hg}$-DOM experiments. In experiments with Chaoborus

269 larvae, uptake of inorganic $\mathrm{Hg}(\mathrm{II})$ and $\mathrm{MeHg}$ decreased from $20 \%$ without DOM to less than $1 \%$

$270 \quad(\mathrm{Hg}(\mathrm{II}))$ and 5\% (MeHg) with DOM. ${ }^{17}$

271 Source and transfer of Hg from DOM to fish. The reduction of $\beta-\mathrm{HgS}_{\mathrm{NP}}$ from $88 \%$ to $37 \%$

272 and associated increase of $\mathrm{Hg}(\mathrm{SR})_{2}$ from $12 \%$ to $63 \%$ in the DOMi-28/DOMf-2 samples (Figure 1)

273 suggests that $\beta-H g S_{N P}$ provided the $\mathrm{Hg}$ that became bioavailable to fish. However, because

274 nanoparticulate $\beta$-HgS that had formed abiotically in DOM ${ }^{37,69}$ was not observed in the fish, the

$275 \beta$-HgS $\mathrm{NP}$ must have dissolved and been transferred to fish in another form, probably through 
exchange of bisthiolate-bound $\mathrm{Hg}$ at the surface of the gill epithelium.

277 Although the solubility of crystalline $\beta-\mathrm{HgS}$ is low $\left(\mathrm{K}_{\mathrm{sp}}\right.$ of $10^{-36.8}$ for the reaction $\mathrm{HgS}_{(\mathrm{s})}+\mathrm{H}^{+}=$

$278 \mathrm{Hg}^{2+}+\mathrm{HS}^{-}$at $\left.25^{\circ} \mathrm{C}\right)^{70}$, the nanoparticulate $\beta-\mathrm{HgS}$ in the DOM would be less stable, or more soluble, 279 than larger crystals ${ }^{71}$ due to excess surface free energy. During the initial aging of the Hg-DOM 280 solutions, the DOM molecules likely adsorbed to nascent particles and slowed their crystal 281 growth, ${ }^{72-75}$ and/or prevented their aggregation. ${ }^{84}$ However, microbial communities in observed

282 DOM-biofilm assemblages in the aquaria could have produced small organic molecules that 283 promoted dissolution of the $\beta$-HgS $\mathrm{NP}_{\mathrm{NP}}$. Periphytic phototrophic microorganisms, such as algae, can

284 increase the bioavailability of $\mathrm{Hg}$ in such biofilms through the exudation of low-molecular-weight 285 (LMW) thiols, including thioglycolic acid, cysteine, and glutathione, ${ }^{38}$ which are known to 286 participate in ligand-promoted dissolution of metal sulfides including nanoparticulate phases. ${ }^{76}$ 287 Graham et al. ${ }^{77}$ observed that Hg was more available for methylation by anaerobic bacteria in the 288 presence of DOM when the solution was slightly supersaturated with respect to $\beta$-HgS, indicating 289 that dissolution of nanoparticulate $\beta-\mathrm{HgS}$ in such systems is possible. Under oxic conditions, 290 however, added $\mathrm{Hg}(\mathrm{II})$ was more bioavailable to a bioreporter bacterium after short pre291 equilibration times ( $\leq 3 \mathrm{~h}$ ) with DOM than when DOM was absent or when $\mathrm{Hg}(\mathrm{II})$ and DOM had 292 pre-reacted for $24 \mathrm{~h} .{ }^{78} \mathrm{~A}$ reaction time of $24 \mathrm{~h}$ would have been sufficient to form $\beta-\mathrm{HgS}_{\mathrm{NP}},{ }^{37,79}$ 293 especially in the Suwannee River DOM used in ref. ${ }^{78}$ because it is as rich in reduced sulfur as 294 peat, ${ }^{45}$ and in this case, nanoparticulate $\beta$-HgS may not have dissolved. Those results also suggest 295 that $\mathrm{Hg}(\mathrm{II})$ associated with smaller nutrient carbon-bearing molecules was able to enter the

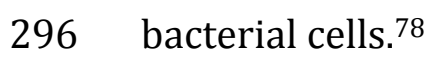

297 We suspect that $\mathrm{Hg}(\mathrm{SR})_{2}$ moieties in the DOM probably were also a source of $\mathrm{Hg}$ to the fish, 298 because in the DOM $\mathrm{M}_{\mathrm{i}}-1453$ experiment this species unambiguously declined in proportion relative 299 to $\beta$-HgS $\mathrm{NP}_{\mathrm{NP}}$ after eight weeks in the aquaria (Figure S3). DOM naturally contains low molecular 
weight molecules. For example, $36 \%$ of the mass of Suwannee River fulvic acids can pass through

301 a dialysis membrane of 100 to 500 Da molecular weight cutoff, ${ }^{80}$ and aqueous peat extracts can

302 permeate through human skin and exert physiological effects. ${ }^{81}$ Also, larger DOM molecules could

303 be rapidly broken down by the activity of microbial heterotrophic communities naturally present

304 in the skin and digestive tract of fish. Upon degradation, DOM could release bioavailable thiol-

305 bound $\mathrm{Hg}(\mathrm{II})$ macromolecules, as has been shown for other metals. ${ }^{82,} 83$ DOM can interact with

306 cell membranes, ${ }^{23}$ increasing their permeability to passive uptake of neutral chemical species. In

307 various freshwater organisms, DOM is taken up directly via epithelia, ${ }^{84}$ and upon exposure to

308 dried DOM, several nonspecific organic transporters were induced in the nematode

309 Caenorhabditis elegans. 85 Once internalized, DOM can migrate to organs or organelles and

310 provoke stress response reactions such as lipid peroxidation, 86 biotransformation activities, 85

311 and induction of chemical defense proteins such as Hsp70.87

312 No MeHg was observed by HR-XANES in either DOM or the fish after eight weeks, presumably

313 because of the oxygenated conditions prevailing in the aquaria and the low concentration of

314 sulfate $(8 \mathrm{mg} / \mathrm{L})$. Even in anaerobic conditions, elevated sulfate is necessary for net methylation

315 of mercury by sulfato-reducing microorganisms. ${ }^{88}$

316 Binding environments of $\mathbf{H g}$ in fish. We conclude that the mercury entered the fish as a low

317 molecular weight molecule in a $\mathrm{Hg}(\mathrm{SR})_{2}$ coordination structure derived either from the DOM or

318 from microbial exudates that dissolved $\beta-\mathrm{HgS}_{\mathrm{NP}}$ in the DOM. Internally, this mercury was

319 transformed to other coordinating environments. In the fish exposed to $\mathrm{Hg}(\mathrm{II})$-spiked DOM, the

320 dominant species ( $84 \pm 8 \%$ of total $\mathrm{Hg}$ equal to $2.2 \mu \mathrm{g} / \mathrm{g}$ ) is a dithiolate complex with

$321 \mathrm{Hg}\left[(\mathrm{SR})_{2}+(\mathrm{N} / 0)_{1-2}\right]$ coordination. The minor species, formed with the remaining $16 \pm 8 \% \mathrm{Hg}$, is a

322 tetrathiolate $\mathrm{Hg}(\mathrm{SR})_{4}$ complex. The fish exposed to $\mathrm{HgCl}_{2}$ (Fish-Hg), which contained $10.4 \mu \mathrm{g}$

$323 \mathrm{Hg} / \mathrm{g}$, has as its dominant species a third $\mathrm{Hg}_{\mathrm{x}} \mathrm{S}_{\mathrm{y}}$ form of larger nuclearity (56 $\left.\pm 15 \%\right)$, with the two 
324 mononuclear complexes in similar lesser proportions $(20-23 \pm 10 \%)$. The coordination

325 environment of $\mathrm{Hg}$ in the three species is discussed below with the goal of indicating possible 326 internal biological pathways for the transformations.

327 The $\mathrm{Hg}\left[(\mathrm{SR})_{2}+(\mathrm{N} / \mathrm{O})_{1-2}\right]$ coordination. Divalent mercury is bonded in the dithiolate complex to 328 two cysteinyl sulfur atoms at $\sim 2.35 \AA$ and to one or two electron donors at 2.5-3.0. . The 329 secondary bonds are nearly perpendicular to the RS-Hg-SR bond axis, and cause the RS-Hg-SR 330 angle to bend more, the shorter the bonds. ${ }^{39,} 89$ The geometry optimizations show that the 331 disphenoidal configuration can be obtained with both $\mathrm{N}$ and $\mathrm{O}$ ligands of different functionalities 332 and molecular conformations. Besides the $\mathrm{Hg}\left((\mathrm{SR})_{2}+\mathrm{O}_{2}\right)$ coordination from $\mathrm{Hg}(\mathrm{GSH})_{2}$ and the $333 \mathrm{Hg}\left(\mathrm{SR}+\mathrm{NH}_{2}\right)_{2}$ coordination from $\mathrm{Hg}(\mathrm{Cys})_{2}$, two intramolecular disphenoidal geometries, both 334 consistent with the HR-XANES results, were modeled. The Hg(Cys+GlyCysGly) model (Figure 335 S8a) features a tetracoordinate double chelate with the cysteinyl $\mathrm{NH}_{2}$ group at $2.57 \AA$ and the 336 carbonyl oxygen of the cysteine residue from the tripeptide at $2.73 \AA$. The oxygen of this 337 functional group is electron rich because of its lone pairs and the $\mathrm{C}=0 \pi$ bond, both favoring a 338 nucleophilic attack on the positive mercury center. The Hg(GlyCysGly) 2 model (Figure S8b) 339 features a tetracoordinate complex with the two 0-terminal carboxylic groups at 2.55 and $2.57 \AA$. 340 Disphenoidal geometry also may occur intermolecularly with side chain amine and guanidyl NH 341 (e.g. from arginine ${ }^{39,}$ 90, 91) groups via protein folding and ligand docking. ${ }^{92-94}$

342 Natural population analysis $\left(\mathrm{NPA}^{95},{ }^{96}\right)$ shows that the partial atomic charge, hence the 343 nucleophilicity, of the $\mathrm{O}$ and $\mathrm{N}$ donors decreases in the following order: $\mathrm{NH}_{2}\left(-0.9\right.$ e) $>\mathrm{COO}^{-}(-0.8$ 344 e) $>\mathrm{C}=\mathrm{O}(-0.7$ e) $>\mathrm{NH}(-0.6$ e) (Figures S1, S4 and S8). Amine and carboxyl groups are more likely 345 to bond $\mathrm{Hg}$ than an amide. Their higher binding strength is reflected in the geometry 346 optimizations by shorter $\mathrm{Hg}_{-} \mathrm{NH}_{2}$ and $\mathrm{Hg}$-COO- bond distances and smaller S-Hg-S angles. 347 However, other factors are involved in the stability of a macromolecular complex, such as the 
348 conformation of the chelate, inter- and intra-molecular packing forces and interactions of the

349 metal with other moieties (e.g., hydrogen bonds). For example, in plants Hg is selectively bonded

350 to the thiol peptide phytochelatin PC2 over GSH, although the GSH concentration largely exceeds

351 the PC2 concentration in the cytosol. ${ }^{97-101}$ PC2 is a GSH dimer with the amino acid sequence $(\gamma$ -

352 Glu-Cys)2-Gly. The strong affinity of Hg for PC2 is explained by the formation of a bis six-

353 membered ring chelate $\mathrm{Hg}[6-\mathrm{S} / 0-\text { ring }]_{2}$ with the thiolate sulfur and carbonyl oxygen atoms from

354 each cysteine residue $\left(\mathrm{Hg}(\mathrm{SR}+0)_{2}\right.$ coordination (Figure S9). ${ }^{51}$ The peptide forms a scaffold for the

355 Hg complex: the two thiolate donors bind Hg like crab claws and the Cys- $\gamma \mathrm{Glu}-\mathrm{Cys}$ molecular cage

356 is stabilized by one hydrogen bond between an amide proton and a carbonyl oxygen

$357(>\mathrm{NH} \ldots \mathrm{O}=\mathrm{C}<)$, as is customary for the secondary structure of proteins. The calculated Hg-O

358 distances are $2.65 \AA$ and $2.95 \AA$ and the SR-Hg-SR bond angle $164.0^{\circ}$, compared to d(Hg-0) $=2.62$

$359 \AA$ and $2.88 \AA$ and an angle of $167.2^{\circ}$ for $\mathrm{Hg}(\mathrm{GSH})_{2}$. As a result, the $\mathrm{Hg}(\mathrm{GSH})_{2}$ and $\mathrm{Hg}(\mathrm{PC} 2)$

360 complexes have similar HR-XANES spectra (Figure S5b).

361 In animal and bacterial cells, $\mathrm{Hg}$ (II) is most commonly bonded to the consensus CXXC motif

362 (single-letter amino acid code, where X can be any amino acid) of metalloproteins with the

$363 \mathrm{Hg}\left[(\mathrm{SR})_{2}+(\mathrm{N} / \mathrm{O})_{1-2}\right]$ coordination. Examples include metallochaperones and metal-transporting

364 ATPases MerP,102 MerA,94 and Atx1 and Ccc2.103, 104 Interestingly, the chain length of the XX

365 sequence $(X=$ Ser, Gly, Ala,... ) from the highly conserved motif GMTCXXC found in

366 metalloproteins ${ }^{105}$ is close to the $\gamma$ Glu length from the CXC motif of PC2.48, 51 Thus, the CXXC motif

367 can cause a distortion from linearity in the same way as $\mathrm{Hg}(\mathrm{PC} 2), \mathrm{Hg}(\mathrm{Cys})_{2}$ and $\mathrm{Hg}(\mathrm{GSH})_{2}$. For

368 example, the S-Hg-S bond angle is $167^{\circ}$ in Atx1. ${ }^{103}$ We conclude that the $\mathrm{Hg}(\mathrm{Cys})_{2}$ and $\mathrm{Hg}(\mathrm{GSH})_{2}$

369 models used in our HR-XANES analysis are good representations of the secondary bonding

370 environment of dithiolated $\mathrm{Hg}$ in fish, whether intermolecular or intramolecular. Despite

371 uncertainty on its exact nature, for energetic reasons $\mathrm{Hg}$ is more likely bonded in a claw setting 
372

373

374

375

376

377

378

379

380

381

382

383

384

385

386

387

388

389

390

391

392

393

394

395

CXXC site of a protein.

The $\mathrm{Hg}(\mathrm{SR})_{4}$ coordination. A high Cys/Hg ratio and non-physiological alkaline $\mathrm{pH}$ are required to form the $\mathrm{Hg}(\mathrm{SR})_{4}$ coordination to low-molecular-weight ligands.54, 57, 106 With proteins, monomeric tetrathiolate coordination has been described only in Hg-substituted rubredoxins, which are iron-sulfur electron-transfer proteins in sulfur-metabolizing bacteria and archaea. ${ }^{107-}$ 109 The rarity of this coordination may be explained by the thermodynamic preference for $\mathrm{Hg}(\mathrm{SR})_{3}$ over $\mathrm{Hg}(\mathrm{SR})_{4}$ coordination from $\mathrm{pH} 4.8$ to 10.6 in biological systems when the thiols are structurally connected. ${ }^{44}$ The trigonal Hg(II)-SR complex is observed for instance in MerR ${ }^{110}$ and the Hah1 metallochaperone. ${ }^{92}$ In $\mathrm{Hg}(\mathrm{Hah} 1)$, $\mathrm{Hg}$ is covalently bonded to three sulfur atoms at 2.3$2.5 \AA$ and weakly bonded to a fourth at $2.8 \AA$. We did not find any evidence for the trigonal coordination in fish, as modeled in our database with $\mathrm{Hg}(\mathrm{D}-\mathrm{Pen})_{3}{ }^{56}$ and $\left[\mathrm{NEt}_{4}\right]\left[\mathrm{Hg}\left(\mathrm{SC}_{6} \mathrm{H}_{11}\right)_{3}\right] . .^{111}$

Four-fold coordination with sulfur atoms occurs, however, in polynuclear structures with thiolate ligands in metallothioneins $\left(\mathrm{Hg}_{\mathrm{x}}(\mathrm{SR})_{\mathrm{y}}\right)^{48,112}$ or with sulfide ligands in $\beta$-HgS. ${ }^{113}$ The second structure model was favored in recent studies on the binding of $\mathrm{Hg}(\mathrm{II})$ to Escherichia coli and Bacillus subtilis under aerobic conditions using EXAFS and XANES spectroscopy.114, 115 The authors identified the $\mathrm{Hg}(\mathrm{SR})_{4}$ coordination and inferred that particulate $\beta$-HgS $(\mathrm{s})$ precipitated from the reaction of biogenic sulfide with $\mathrm{Hg}(\mathrm{SR})_{2}$.

Here, we favor the metallothionein (MT) interpretation because if $\beta$-HgS nanoparticles existed they should have been detectable by high energy-resolution XANES at liquid helium temperature. Fish metallothioneins have two metal binding domains. The $\alpha$ domain can bind four $\mathrm{Hg}$ atoms in $\mathrm{Hg}_{4} \mathrm{Cys}_{11}$ cluster and the $\beta$ domain three $\mathrm{Hg}$ atoms in a $\mathrm{Hg}_{3} \mathrm{Cys} 9 \mathrm{Hg}_{3} \mathrm{Cys} 9$ cluster (Figure 4b).48, 116 In each cluster the $\mathrm{Hg}(\mathrm{Cys})_{4}$ tetrahedra are connected through their apices with a $\beta$-HgS-type core structure (Figure 4c). Metallothionein nanoclusters with nuclearity of only three to four are vanishingly small compared for example to $\beta$-HgS nanocrystals of $3-5 \mathrm{~nm}$ in 
diameter observed by HRTEM in natural organic matter. ${ }^{37} \mathrm{An} \alpha-\mathrm{Hg}_{4} \mathrm{Cys} 11$ cluster has on average

$3972.5 \mathrm{Hg}$-Hg pairs at 4.1-4.4 $\AA$ and a $\beta$-Hg 3 Cys9 cluster only 2, compared to 12 in $\beta$-HgS. ${ }^{113}$ Both

398 clusters lack any Hg-Hg pairs beyond $7 \AA$ A. Because of the structural disorder and reduced size of

399 a MT $\mathrm{Hg}_{\mathrm{x}}(\mathrm{SR})_{\mathrm{y}}$ core, the same HR-XANES fine structures that are associated with $\mathrm{Hg}-\mathrm{Hg}$ pairs as

400 seen in the $\beta-H g S_{N P}$ reference are smeared together and cannot be distinguished. A

401 metallothionein HR-XANES spectrum with a polynuclear core has a bell-shaped top edge with no

402 distinct modulation of the absorption signal: it appears like the spectrum from the $\mathrm{Hg}(\mathrm{Cys})_{4}$

403 reference, even though some Hg-Hg pairs are present. ${ }^{48,51}$

404

The $\mathrm{Hg}_{\mathrm{x}} \mathrm{S}_{y}$ coordination. Based on XANES calculations, ${ }^{117,118}$ a $\beta-\mathrm{Hg} \mathrm{g}_{\mathrm{y}}$ cluster size of at least 1

$405 \mathrm{~nm}$ is required to produce the $\mathrm{Hg}-\mathrm{Hg}$ multiple scattering events at the origin of the fine structures

406 in the HR-XANES spectrum of Fish-Hg (Figure S6a). This minimum size corresponds to a

407 stoichiometry of $\beta-\mathrm{Hg}_{7} \mathrm{~S}_{16}$, which exceeds the maximum nuclearity of $\mathrm{Hg}_{4} \mathrm{~S}_{11}$ for the MT clusters.

408 Therefore, the $\mathrm{Hg}_{\mathrm{x}} \mathrm{S}_{\mathrm{y}}$ coordination of Fish-Hg is most likely from particulate $\beta$-HgS which could

409 form in the reducing environment of the cytosol by the reaction of $\mathrm{Hg}(\mathrm{SR})_{2}$ with hydrogen

410 (mono)sulfide ( $\left.\mathrm{H}_{2} \mathrm{~S} / \mathrm{HS}-\right)^{114,115}$

411 The absence of compelling evidence for nanoparticulate $\beta$-HgS in Fish-DOM can be explained,

412 at least in part, by the fact that fish from the DOM experiment had only $20 \%$ of the $\mathrm{Hg}$ that was in

413 fish from the $\mathrm{HgCl}_{2}$ experiment. The dithiolate and tetrathiolate $\mathrm{Hg}$ species, which coexist in both

414 Fish-DOM and Fish-Hg, are probably more representative of the forms of inorganic Hg at

415 environmental concentrations. Lastly, although the same, or closely related, $\beta$-HgS-type

416 nanoparticles occur in DOM and in Fish-Hg, the DOM nanoparticles most likely transformed

417 externally to $\mathrm{Hg}(\mathrm{SR})_{2}$ prior to mercury incorporation in fish tissue. Furthermore, the two mercury

418 sulfides formed by different reaction pathways. In Hg-DOM, the $\beta$-HgS nanocrystals were

419 produced under aerated conditions from $\mathrm{Hg}(\mathrm{SR})_{2}$ by a dealkylation reaction, ${ }^{37,69}$ whereas in fish 
420 the $\beta-\mathrm{Hg}_{\mathrm{x}} \mathrm{S}_{\mathrm{y}}$ clusters were likely formed by reaction of $\mathrm{Hg}(\mathrm{SR})_{2}$ with biogenic sulfide. ${ }^{114}, 115$

421 Although most mercury in fish tissue is methylmercury, ${ }^{66}$ the presence in fish of any of the

422 structures observed in the Fish-DOM or Fish-Hg spectra would be a biomarker of an inorganic Hg

423 source and may have potential for forensic applications.

\section{ASSOCIATED CONTENT}

\section{Supporting Information}

427 The Supporting Information is available free of charge on the ACS Publications website at DOI:

428 Supplemental information on materials and methods, Supplementary Tables and Figures,

429 Cartesian coordinates of the $\mathrm{Hg}(\mathrm{Cys})_{2}$ and $\mathrm{Hg}(\mathrm{GSH})_{2}$ complexes, $\mathrm{Hg}_{4}(\mathrm{SMe})_{11-\alpha} \alpha$ and $\mathrm{Hg}_{3}\left(\mathrm{SMe}_{9}-\beta\right.$

430 clusters, and HR-XANES spectra (PDF). Video S1 showing the structures of Hg(GSH)2.

\section{AUTHOR INFORMATION}

\section{Corresponding Authors}

434 E-mail: jean-paul.bourdineaud@u-bordeaux.fr

435 E-mail: alain.manceau@univ-grenoble-alpes.fr

$436 \quad$ Notes

437 The authors declare no competing financial interests.

\section{ACKNOWLEDGMENTS}

440 Support was provided to A.M, M.G-R., K.L.N., and J-P.B. by the French National Research Agency 441 (ANR) under grant ANR-12-BS06-0008-01, to A.M., M.R., and P.G. by the ANR under grant ANR442 10-EQPX-27-01 (EcoX Equipex), and to K.L.N. by the U.S. National Science Foundation under grant 443 EAR-1628956. The Froggy platform of the CIMENT infrastructure (ANR Grant ANR-10-EQPX- 29444 01) provided computing resources and Pierre Girard his expertise in parallel scientific processing. 445 Martine Lanson synthesized the Hg-DOM and performed Hg analyses with Aude Wack.

447 REFERENCES 
(1) Phillips, G. R.; Buhler, D. R., The relative contributions of methylmercury from food or water to rainbow-trout (Salmo gairdneri) in a controlled laboratory environment. Trans. Am. Fish. Soc. 1978, 107, 853-861.

451 (2) Rodgers, D. W.; Qadri, S. U., Growth and mercury accumulation in yearling yellow perch, 452 Perca flavescens, in the Ottawa River, Ontario. Environ. Biol. Fish. 1982, 7, 377-383.

(3) Meili, M., Fluxes, pools, and turnover of mercury in swedish forest lakes. Water Air Soil Poll. 1991, 56, 719-727.

(4) Spry, D. J.; Wiener, J. G., Metal bioavailability and toxicity to fish in low-alkalinity lakes - A critical review. Environ. Pollut. 1991, 71, 243-304.

(5) Hall, B. D.; Bodaly, R. A.; Fudge, R. J. P.; Rudd, J. W. M.; Rosenberg, D. M., Food as the dominant pathway of methylmercury uptake by fish. Water Air Soil Poll. 1997, 100, 13-24.

(6) Hrenchuk, L. E.; Blanchfield, P. J.; Paterson, M. J.; Hintelmann, H. H., Dietary and waterborne mercury accumulation by yellow perch: A field experiment. Environ. Sci. Technol. 2012, 46, 509461516.

462 (7) Post, J. R.; Vandenbos, R.; McQueen, D. J., Uptake rates of food-chain and waterborne mercury by fish: Field measurements, a mechanistic model, and an assessment of uncertainties. Can. J. Fish. Aquat. Sci. 1996, 53, 395-407.

(8) Haitzer, M.; Aiken, G. R.; Ryan, J. N., Binding of mercury(II) to dissolved organic matter: The role of the mercury-to-DOM concentration ratio. Environ. Sci. Technol. 2002, 36, 3564-3570.

(9) Ramamoorthy, S.; Blumhagen, K., Uptake of $\mathrm{Zn}, \mathrm{Cd}$, and $\mathrm{Hg}$ by fish in the presence of competing compartments. Can. J. Fish. Aquat. Sci. 1984, 41, 750-756.

(10) Grieb, T. M.; Driscoll, C. T.; Gloss, S. P.; Schofield, C. L.; Bowie, G. L.; Porcella, D. B., Factors 472 (11) Playle, R. C.; Dixon, D. G.; Burnison, K., Copper and cadmium-binding to fish gills Modification by dissolved organic-carbon and synthetic ligands. Can. J. Fish. Aquat. Sci. 1993, 50, affecting mercury accumulation in fish in the Upper Michigan peninsula. Environ. Toxicol. Chem. 1990, 9, 919-930. 2667-2677.

(12) Back, R. C.; Watras, C. J., Mercury in zooplankton of northern Wisconsin lakes - Taxonomic and site-specific trends. Water Air and Soil Poll. 1995, 80, 931-938.

(13) Driscoll, C. T.; Blette, V.; Yan, C.; Schofield, C. L.; Munson, R.; Holsapple, J., The role of dissolved organic carbon in the chemistry and bioavailability of mercury in remote Adirondack lakes. Water Air and Soil Poll. 1995, 80, 499-508. 
(14) Hollis, L.; Muench, L.; Playle, R. C., Influence of dissolved organic matter on copper binding, and calcium on cadmium binding, by gills of rainbow trout. J. Fish Biol. 1997, 50, 703-720.

482 (15) Penttinen, S.; Kostamo, A.; Kukkonen, J. V. K., Combined effects of dissolved organic material and water hardness on toxicity of cadmium to Daphnia magna. Environ. Toxicol. Chem. 1998, 17, 2498-2503.

(16) Richards, J. G.; Burnison, B. K.; Playle, R. C., Natural and commercial dissolved organic matter protects against the physiological effects of a combined cadmium and copper exposure on rainbow trout (Oncorhynchus mykiss). Can. J. Fish. Aquat. Sci. 1999, 56, 407-418.

(17) Sjoblom, A.; Meili, M.; Sundbom, M., The influence of humic substances on the speciation and bioavailability of dissolved mercury and methylmercury, measured as uptake by Chaoborus larvae and loss by volatilization. Sci. Tot. Environ. 2000, 261, 115-124.

(18) Richards, J. G.; Curtis, P. J.; Burnison, B. K.; Playle, R. C., Effects of natural organic matter source on reducing metal toxicity to rainbow trout (Oncorhynchus mykiss) and on metal binding to their gills. Environ. Tox. Chem. 2001, 20, 1159-1166.

494 (19) Meinelt, T.; Playle, R. C.; Pietrock, M.; Burnison, B. K.; Wienke, A.; Steinberg, C. E. W., Interaction of cadmium toxicity in embryos and larvae of zebrafish (Danio rerio) with calcium and humic substances. Aquat. Toxicol. 2001, 54, 205-215.

497 (20) Van Ginneken, L.; Bervoets, L.; Blust, R., Bioavailability of Cd to the common carp, Cyprinus carpio, in the presence of humic acid. Aquat. Toxicol. 2001, 52, 13-27.

499 (21) Hammock, D.; Huang, C. C.; Mort, G.; Swinehart, J. H., The effect of humic acid on the uptake 500 of mercury(II), cadmium(II), and zinc(II) by Chinook salmon (Oncorhynchus tshawytscha) eggs. 501 Arch. Environ. Con. Tox. 2003, 44, 83-88.

502 (22) Burnison, B. K.; Meinelt, T.; Playle, R.; Pietrock, M.; Wienke, A.; Steinberg, C. E. W., Cadmium 503 accumulation in zebrafish (Danio rerio) eggs is modulated by dissolved organic matter (DOM). 504 Aquat. Toxicol. 2006, 79, 185-191.

505 (23) Koukal, B.; Gueguen, C.; Pardos, M.; Dominik, J., Influence of humic substances on the toxic 506 effects of cadmium and zinc to the green alga Pseudokirchneriella subcapitata. Chemosphere 2003, 507 53, (8), 953-961.

508 (24) Mannio, J.; Verta, M.; P., K.; Rekolainen, S., The effect of water quality on the mercury 509 concentration of northern pike (Esox lucius L.) in Finnish forest lakes and reservoirs. Water Res. 510 Inst. National Board of Waters, Helsinki, Pub. 1986, 65, 32-43. 
511 (25) McMurtry, M. J.; Wales, D. L.; Scheider, W. A.; Beggs, G. L.; Dimond, P. E., Relationship of 512 mercury concentrations in lake trout (Salvelinus namaycush) and smallmouth bass (Micropterus 513 dolomieui) to the physical and chemical characteristics of Ontario lakes. Can. J. Fish. Aquat. Sci. 514 1989, 46, 426-434.

515 (26) Hakanson, L.; Andersson, T.; Nilsson, A., Mercury in fish in Swedish lakes - Linkages to 516 domestic and European sources of emission. Water Air Soil Poll. 1990, 50, 171-191.

517 (27) Wren, C. D.; Scheider, W. A.; Wales, D. L.; Muncaster, B. W.; Gray, I. M., Relation between 518 mercury concentrations in walleye (Stizostedion vitreum vitreum) and northern pike (Esox lucius) 519 in Ontario lakes and influence of environmental factors. Can. J. Fish Aquat. Sci. 1991, 48, 132-139.

520 (28) Penttinen, S.; Kukkonen, J.; Oikari, A., The kinetics of cadmium in Daphnia magna as 521 affected by humic substances and water hardness. Ecotox. Environ. Safe. 1995, 30, 72-76.

522 (29) Watras, C. J.; Back, R. C.; Halvorsen, S.; Hudson, R. J. M.; Morrison, K. A.; Wente, S. P., 523 Bioaccumulation of mercury in pelagic freshwater food webs. Sci. Tot. Environ. 1998, 219, 183524208.

525 (30) French, T. D.; Houben, A. J.; Desforges, J. P. W.; Kimpe, L. E.; Kokelj, S. V.; Poulain, A. J.; Smol, 526 J. P.; Wang, X. W.; Blais, J. M., Dissolved organic carbon thresholds affect mercury bioaccumulation 527 in Arctic lakes. Environ. Sci. Technol. 2014, 48, 3162-3168.

528 (31) Winner, R. W., The toxicity and bioaccumulation of cadmium and copper as affected by 529 humic-acid. Aquat. Toxicol. 1984, 5, 267-274.

530 (32) Oikari, A.; Kukkonen, J.; Virtanen, V., Acute toxicity of chemicals to Daphnia magna in humic 531 waters. Sci. Tot. Environ. 1992, 118, 367-377.

532 (33) Kozuch, J.; Pempkowiak, J., Molecular weight of humic acids as a major property of the 533 substances influencing the accumulation rate of cadmium by a blue mussel (Mytilus edulis). 534 Environ. Int. 1996, 22, 585-589.

535 (34) Graham, A. M.; Aiken, G. R.; Gilmour, C. C., Dissolved organic matter enhances microbial 536 mercury methylation under sulfidic conditions. Environ. Sci. Technol. 2012, 46, 2715-2723.

537 (35) Skyllberg, U.; Bloom, P. R.; Qian, J.; Lin, C. M.; Bleam, W. F., Complexation of mercury(II) in 538 soil organic matter: EXAFS evidence for linear two-coordination with reduced sulfur groups. 539 Environ. Sci. Technol. 2006, 40, 4174-4180.

540 (36) Manceau, A.; Lemouchi, C.; Rovezzi, M.; Lanson, M.; Glatzel, P.; Nagy, K. L.; Gautier-Luneau, 541 I.; Joly, Y.; Enescu, M., Structure, bonding, and stability of mercury complexes with thiolate and 
542 thioether ligands from high-resolution XANES spectroscopy and first-principles calculations. 543 Inorg. Chem. 2015, 54, 11776-11791.

544 (37) Manceau, A.; Lemouchi, C.; Enescu, M.; Gaillot, A.-C.; Lanson, M.; Magnin, V.; Glatzel, P.; 545 Poulin, B. A.; Ryan, J. N.; Aiken, G. R.; Gautier-Luneau, I.; Nagy, K. L., Formation of mercury sulfide 546 from $\mathrm{Hg}$ (II)-thiolate complexes in natural organic matter. Environ. Sci. Technol. 2015, 49, 547 9787-9796.

548 (38) Leclerc, M.; Planas, D.; Amyot, M., Relationship between extracellular low-molecular549 weight thiols and mercury species in natural lake periphytic biofilms. Environ. Sci. Technol. 2015, $55049,7709-7716$.

551 (39) Manceau, A.; Enescu, M.; Simionovici, A.; Lanson, M.; Gonzalez-Rey, M.; Rovezzi, M.; 552 Tucoulou, R.; Glatzel, P.; Nagy, K. L.; Bourdineaud, J.-P., Chemical forms of mercury in human hair 553 reveal sources of exposure. Environ. Sci. Technol. 2016, 50, 10721-10729.

554 (40) Mitchell, C. P. J.; Branfireun, B. A.; Kolka, R. K., Spatial characteristics of net methylmercury 555 production hot spots in peatlands. Environ. Sci. Technol. 2008, 42, 1010-1016.

556 (41) Suhett, A. L.; Amado, A. M.; Enrich-Prast, A.; de Assis Esteves, F.; Farjalla, V. F., Seasonal 557 changes of dissolved organic carbon photo-oxidation rates in a tropical humic lagoon: the role of 558 rainfall as a major regulator. Can. J. Fish. Aquat. Sci. 2007, 64, 1266-1272.

559 (42) Suhett, A. L.; Amado, A. M.; Meirelles-Pereira, F.; Scofield, V.; Jacques, S. M. d. S.; Laque, T.; 560 Farjalla, V. F., Origin, concentration, availability and fate of dissolved organic carbon in coastal 561 lagoons of the Rio de Janeiro State. Acta Limn. Brasil. 2013, 25, 326-340.

562 (43) U.S. National Archives and Records Administration. 2018. Code of federal regulations. Title 563 40. Protection of Environment, Part 14. National Primary Drinking Water Regulations.

564 (44) Manceau, A.; Matynia, A., The nature of $\mathrm{Cu}$ bonding to natural organic matter. Geochim. 565 Cosmochim. Acta 2010, 74, 2556-2580.

566 (45) Manceau, A.; Nagy, K. L., Quantitative analysis of sulfur functional groups in natural organic 567 matter by XANES spectroscopy. Geochim. Cosmochim. Acta 2012, 99, 206-223.

568 (46) NIH, Guidelines for use of zebrafish in the NIH intramural research program. 569 http://oacu.od.nih.gov/ARAC/documents/Zebrafish.pdf 2013.

570 (47) George, G. N.; Pickering, I. J.; Pushie, M. J.; Nienaber, K.; Hackett, M. J.; Ascone, I.; Hedman, 571 B.; Hodgson, K. O.; Aitken, J. B.; Levina, A.; Glover, C.; Lay, P. A., X-ray-induced photo-chemistry and 572 X-ray absorption spectroscopy of biological samples. J. Synch. Rad. 2012, 19, 875-886. 
(48) Manceau, A.; Bustamante, P.; Haouz, A.; Bourdineaud, J. P.; Gonzalez-Rey, M.; Geertsen, V.;

574 Barruet, E.; Rovezzi, M.; Glatzel, P.; Pin, S., Mercury(II) binding to metallothionein in Mytilus edulis 575 revealed by high energy-resolution XANES spectroscopy. Chemistry - A European Journal 2018, 576 doi.org/10.1002/chem.201804209.

577 (49) Gonzalez, P.; Dominique, Y.; Massabuau, J. C.; Boudou, A.; Bourdineaud, J. P., Comparative 578 effects of dietary methylmercury on gene expression in liver, skeletal muscle, and brain of the 579 zebrafish (Danio rerio). Environ. Sci. Technol. 2005, 39, 3972-3980.

580 (50) Rovezzi, M.; Lapras, C.; Manceau, A.; Glatzel, P.; Verbeni, R., High energy-resolution x-ray 581 spectroscopy at ultra-high dilution with spherically bent crystal analyzers of $0.5 \mathrm{~m}$ radius. Rev. 582 Sci. Instr. 2017, 88, 013108.

583 (51) Manceau, A.; Wang, J.; Rovezzi, M.; Glatzel, P.; Feng, X., Biogenesis of mercury-sulfur 584 nanoparticles in plant leaves from atmospheric gaseous mercury. Environ. Sci. Technol. 2018, 52, 585 3935-3948.

586 (52) Lannes, A.; Manceau, A.; Rovezzi, M.; Glatzel, P.; Joly, Y.; Gautier-Luneau, I., Intramolecular 587 Hg... $\pi$ interactions of d-character with non-bridging atoms in mercury-aryl complexes. Dalton 588 Trans. 2016, 45, 14035-14038.

589 (53) Neese, F., The ORCA program system. WIREs Comput. Mol. Sci. 2011, 2, 73-78.

590 (54) Enescu, M.; Manceau, A., High-level ab initio calculation of the stability of mercury-thiolate 591 complexes. Theor. Chem. Acc. 2014, 133, nº 1457.

592 (55) Fleischer, H.; Dienes, Y.; Mathiasch, B.; Schmitt, V.; Schollmeyer, D., Cysteamine and its 593 homoleptic complexes with group 12 metal ions. Differences in the coordination chemistry of Zn594 II, Cd-II, and Hg-II with a small N,S-donor ligand. Inorg. Chem. 2005, 44, 8087-8096.

595 (56) Leung, B. O.; Jalilehvand, F.; Mah, V., Mercury(II) penicillamine complex formation in 596 alkaline aqueous solution. Dalton Trans. 2007, 4666-4674.

597 (57) Warner, T.; Jalilehvand, F., Formation of $\mathrm{Hg}(\mathrm{II})$ tetrathiolate complexes with cysteine at 598 neutral pH. Can. J. Chem. 2016, 94, 1-7.

599 (58) Bianconi, A.; Dell'Ariccia, M.; Gargano, A.; Natoli, C. R., Bond length determination using 600 XANES. In EXAFS and Near Edge Structure, Bianconi, A.; Incoccia, A.; Stipcich, S., Eds. Springer, 601 Berlin: 1983; Vol. 27, pp 57-61.

602 (59) Harris, H. H.; Pickering, I. J.; G.N., G., The chemical form of mercury in fish. Science 2003, $603301,1203$. 
(60) Arai, T.; Ikemoto, T.; Hokura, A.; Terada, Y.; Kunito, T.; Tanabe, S.; Nakai, I., Chemical forms 605 of mercury and cadmium accumulated in marine mammals and seabirds as determined by XAFS 606 analysis. Environ. Sci. Technol. 2004, 38, 6468-6474.

607 (61) Ikemoto, T.; Kunito, T.; Tanaka, H.; Baba, N.; Miyazaki, N.; Tanabe, S., Detoxification 608 mechanism of heavy metals in marine mammals and seabirds: Interaction of selenium with 609 mercury, silver, copper, zinc, and cadmium in liver. Arch. Environ. Con. Tox. 2004, 47, 402-413.

610 (62) Endo, T.; Kimura, O.; Hisamichi, Y.; Minoshima, Y.; Haraguchi, K.; Kakumoto, C.; Kobayashi, 611 M., Distribution of total mercury, methyl mercury and selenium in pod of killer whales (Orcinus 612 Orca) stranded in the northern area of Japan: Comparison of mature females with calves. Environ. 613 Poll. 2006, 144, 145-150.

614 (63) Huggins, F. E.; Raverty, S. A.; Nielsen, O. S.; Sharp, N. E.; Robertson, J. D.; Ralston, N. V. C., An 615 XAFS investigation of mercury and selenium in Beluga whale tissues. Environ. Bioindic. 2009, 4, $616 \quad 291-302$.

617 (64) Nakazawa, E.; Ikemoto, T.; Hokura, A.; Terada, Y.; Kunito, T.; Tanabe, S.; Nakai, I., The 618 presence of mercury selenide in various tissues of the striped dolphin: evidence from mu-XRF619 XRD and XAFS analyses. Metallomics 2011, 3, 719-725.

620 (65) Lyytikainen, M.; Patynen, J.; Hyvarinen, H.; Sipila, T.; Kunnasranta, M., Mercury and 621 selenium balance in endangered saimaa ringed seal depend on age and sex. Environ. Sci. Technol. $622 \quad 2015,49,11808-11816$.

623 (66) Nevado, J. J. B.; Martin-Doimeadios, R. C. R.; Bernardo, F. J. G.; Moreno, M. J.; Herculano, A. 624 M.; do Nascimento, J. L. M.; Crespo-Lopez, M. E., Mercury in the Tapajos River basin, Brazilian 625 Amazon: A review. Environ. Int. 2010, 36, 593-608.

626 (67) Mathews, T. J.; Southworth, G.; Peterson, M. J.; Roy, W. K.; Ketelle, R. H.; Valentine, C.; 627 Gregory, S., Decreasing aqueous mercury concentrations to meet the water quality criterion in 628 fish: Examining the water-fish relationship in two point-source contaminated streams. Sci. Tot. 629 Environ. 2013, 443, 836-843.

630 (68) Bourdineaud, J. P.; Durrieu, G.; Sarrazin, S. L. F.; da Silva, W. C. R.; Mourao, R. H. V.; de 631 Oliveira, R. B., Mercurial exposure of residents of Santarem and Oriximina cities (Para, Brazil) 632 through fish consumption. Environ. Sci. Pollut. Res. 2015, 22, 12150-12161.

633 (69) Enescu, M.; Nagy, K. L.; Manceau, A., Nucleation of mercury sulfide by dealkylation. Sci. Rep. $6342016,6,39359$. 
635 (70) Drott, A.; Björn, E.; Boucher, S.; Skyllberg, U., Refining thermodynamic constants for 636 mercury(II)-sulfides in equilibrium with metacinnabar at sub-micromolar aqueous sulfide 637 concentrations. Environ. Sci. Technol. 2013, 47, 4197-4203.

638 (71) Liu, J.; Aruguete, D. M.; Murayama, M.; Hochella, M. F., Influence of size and aggregation on 639 the reactivity of an environmentally and industrially relevant nanomaterial (PbS). Environ. Sci. 640 Technol. 2009, 43, 8178-8183.

641 (72) Ravichandran, R.; Aiken, G. R.; Ryan, J. N.; Reddy, M. M., Inhibition of precipitation and 642 aggregation of metacinnabar (mercuric sulfide) by dissolved organic matter isolated from the 643 Florida Everglades. Environ. Sci. Technol. 1999, 33, 1418-1423.

644 (73) Gerbig, C. A.; Kim, C. S.; Stegemeier, J. P.; Ryan, J. N.; Aiken, G. R., Formation of nanocolloidal 645 metacinnabar in mercury-D0M-sulfide systems. Environ. Sci. Technol. 2011, 45, 9180-9187.

646 (74) Deonarine, A.; Hsu-Kim, H., Precipitation of mercuric sulfide nanoparticles in NOM647 containing water: Implications for the natural environment. Environ. Sci. Technol. 2009, 43, 23686482373.

649 (75) Slowey, A. J., Rate of formation and dissolution of mercury sulfide nanoparticles: The dual 650 role of natural organic matter. Geochim. Cosmochim. Acta 2010, 74, 4693-4708.

651 (76) Marchioni, M.; Gallon, T.; Worms, I.; Jouneau, P. H.; Lebrun, C.; Veronesi, G.; Truffier-Boutry, 652 D.; Mintz, E.; Delangle, P.; Deniaud, A.; Michaud-Soret, I., Insights into polythiol-assisted AgNP 653 dissolution induced by bio-relevant molecules. Environ. Sci. Nano 2018, 5, 1911-1920.

654 (77) Graham, A. M.; Aiken, G. R.; Gilmour, C. C., Effect of dissolved organic matter source and 655 character on microbial Hg methylation in Hg-S-DOM solutions. Environ. Sci. Technol. 2013, 47, $656 \quad 5746-5754$

657 (78) Chiasson-Gould, S. A.; Blais, J. M.; Poulain, A. J., Dissolved organic matter kinetically controls 658 mercury bioavailability to bacteria. Environ. Sci. Technol. 2014, 48, 3153-3161.

659 (79) Nagy, K. L.; Manceau, A.; Gasper, J. D.; Ryan, J. N.; Aiken, G. R., Metallothionein-like 660 multinuclear clusters of mercury(II) and sulfur in peat. Environ. Sci. Technol. 2011, 45, 72986617306.

662 (80) Remucal, C. K.; Cory, R. M.; Sander, M.; McNeill, K., Low molecular weight components in an 663 aquatic humic substance as characterized by membrane dialysis and orbitrap mass spectrometry. 664 Environ. Sci. Technol. 2012, 46, 9350-9359.

665 (81) Beer, A. M.; Junginger, H. E.; Lukanov, J.; Sagorchev, P., Evaluation of the permeation of peat 666 substances through human skin in vitro. Int. J. Pharm. 2003, 253, 169-175. 
(82) Masson, M.; Blanc, G.; Schafer, J.; Parlanti, E.; Le Coustumer, P., Copper addition by organic 668 matter degradation in the freshwater reaches of a turbid estuary. Sci. Tot. Environ. 2011, 409, 669 1539-1549.

670 (83) Wengel, M.; Kothe, E.; Schmidt, C. M.; Heide, K.; Gleixner, G., Degradation of organic matter 671 from black shales and charcoal by the wood-rotting fungus Schizophyllum commune and release 672 of DOC and heavy metals in the aqueous phase. Sci. Tot. Environ. 2006, 367, 383-393.

673 (84) Steinberg, C. E. W.; Meinelt, T.; Timofeyev, M. A.; Bittner, M.; Menzel, R., Humic substances. 674 Environ. Sci. Pollut. Res. 2008, 15, 128-135.

675 (85) Menzel, R.; Sturzenbaum, S.; Barenwaldt, A.; Kulas, J.; Steinberg, C. E. W., Humic material 676 induces behavioral and global transcriptional responses in the nematode Caenorhabditis elegans. 677 Environ. Sci. Technol. 2005, 39, 8324-8332.

678 (86) Timofeyev, M. A.; Shatilina, Z. M.; Kolesnichenko, A. V.; Bedulina, D. S.; Kolesnichenko, V. V.; 679 Pflugmacher, S.; Steinberg, C. E. W., Natural organic matter (NOM) induces oxidative stress in 680 freshwater amphipods Gammarus lacustris Sars and Gammarus tigrinus (Sexton). Sci. Tot. Environ. $6812006,366,673-681$.

682 (87) Timofeyev, M. A.; Wiegand, C.; Burnison, B. K.; Shatilina, Z. M.; Pflugmacher, S.; Steinberg, 683 C. E. W., Direct impact of natural organic matter (NOM) on freshwater amphipods. . Sci. Total 684 Environ. 2004, 319, 115-121.

685 (88) Zhang, T.; Kucharzyk, K. H.; Kim, B.; Deshusses, M. A.; Hsu-Kim, H., Net methylation of 686 mercury in estuarine sediment microcosms amended with dissolved, nanoparticulate, and 687 microparticulate mercuric sulfides. Environ. Sci. Technol. 2014, 48, 9133-9141.

688 (89) Manceau, A.; Nagy, K. L., Relationships between $\mathrm{Hg}(\mathrm{II})-\mathrm{S}$ bond distance and $\mathrm{Hg}(\mathrm{II})$ 689 coordination in thiolates. Dalton Trans. 2008, 11, 1421-1425.

690 (90) Ratilla, E. M. A.; Kostic, N. M., Guanidyl groups - New metal-binding ligands in biomolecules 691 - Reactions of chloro(2,2'.6',2"-terpyridine)platinum(II) with arginine in 2 cytochromes $\mathrm{C}$ and 692 with other guanidyl ligands. J. Am.. Chem. Soc. 1988, 110, 4427-4428.

693 (91) Ratilla, E. M. A.; Scott, B. K.; Moxness, M. S.; Kostic, N. M., Terminal and new bridging 694 coordination of methylguanidine, arginine, and canavanine to platinum(II) - The 1st 695 crystallographic study of bonding between a transition-metal and a guanidine ligand. Inorg. Chem. 696 1990, 29, 918-926. 
(92) Wernimont, A. K.; Huffman, D. L.; Lamb, A. L.; O'Halloran, T. V.; Rosenzweig, A. C., Structural

698 basis for copper transfer by the metallochaperone for the Menkes/Wilson disease proteins. 699 Nature Str. Biol. 2000, 7, 766-771.

700 (93) Luczkowski, M.; Zeider, B. A.; Hinz, A. V. H.; Stachura, M.; Chakraborty, S.; Hemmingsen, L.;

701 Huffman, D. L.; Pecoraro, V. L., Probing the coordination environment of the human copper 702 chaperone HAH1: Characterization of HgII-bridged homodimeric species in solution. Chem. Eur. J. $703 \quad 2013,19,9042-9049$.

704 (94) Lian, P.; Guo, H. B.; Riccardi, D.; Dong, A. P.; Parks, J. M.; Xu, Q.; Pai, E. F.; Miller, S. M.; Wei, 705 D. Q.; Smith, J. C.; Guo, H., X-ray structure of a $\mathrm{Hg}^{2+}$ complex of mercuric reductase (MerA) and 706 quantum mechanical/molecular mechanical study of $\mathrm{Hg}^{2+}$ transfer between the C-terminal and buried catalytic site cysteine pairs. Biochemistry 2014, 53, 7211-7222.

(95) Reed, A. E.; Curtiss, L. A.; Weinhold, F., Intermolecular interactions from a natural bond 709 orbital, donor-acceptor viewpoint. Chem. Rev. 1988, 88, 899-926.

(96) Glendening, E. D.; Landis, C. R.; Weinhold, F., NBO 6.0: Natural bond orbital analysis 711 program. J. Comput. Chem. 2013, 34, 1429-1437.

712 (97) Mehra, R. K.; Miclat, J.; Kodati, V. R.; Abdullah, R.; Hunter, T. C.; Mulchandani, P., Optical 713 spectroscopic and reverse-phase HPLC analyses of $\mathrm{Hg}$ (II) binding to phytochelatins. Biochem. J. 714 1996, 314, 73-82.

(98) Krupp, E. M.; Mestrot, A.; Wielgus, J.; Meharg, A. A.; Feldmann, J., The molecular form of mercury in biota: identification of novel mercury peptide complexes in plants. Chem. Comm. 2009, $717 \quad 28,4257-4259$.

718 (99) Carrasco-Gil, S.; Alvarez-Fernandez, A.; Sobrino-Plata, J.; Millan, R.; Carpena-Ruiz, R. O.; 719 Leduc, D. L.; Andrews, J. C.; Abadia, J.; Hernandez, L. E., Complexation of Hg with phytochelatins is 720 important for plant Hg tolerance. Plant Cell Environ. 2011, 34, 778-791.

721 (100) Kawakami, S. K.; Achterberg, E. P., Particulate thiol peptides along a salinity gradient of a 722 metal-contaminated estuary. Estuar. Coast. 2012, 35, 658-664.

723 (101)Dago, A.; Gonzalez, I.; Arino, C.; Martinez-Coronado, A.; Higueras, P.; Diaz-Cruz, J. M.; 724 Esteban, M., Evaluation of mercury stress in plants from the Almaden mining district by analysis 725 of phytochelatins and their Hg complexes. Environ. Sci. Technol. 2014, 48, 6256-6263.

726 (102)Steele, R. A.; Opella, S. J., Structures of the reduced and mercury-bound forms of MerP, the 727 periplasmic protein from the bacterial mercury detoxification system. Biochemistry 1997, 36, 728 6885-6895. 
730 V., Crystal structure of the Atx1 metallochaperone protein at 1.02 angstrom resolution. Structure 731 1999, 7, 605-617.

732 (104) Banci, L.; Bertini, I.; Cantini, F.; Felli, I. C.; Gonnelli, L.; Hadjiliadis, N.; Pierattelli, R.; Rosato, 733 A.; Voulgaris, P., The Atx1-Ccc2 complex is a metal-mediated protein-protein interaction. Nature 734 Chem. Biol. 2006, 2, 367-368.

735 (105)Arnesano, F.; Banci, L.; Bertini, I.; Ciofi-Baffoni, S.; Molteni, E.; Huffman, D. L.; O'Halloran, T. 736 V., Metallochaperones and metal-transporting ATPases: A comparative analysis of sequences and 737 structures. Genome Res. 2002, 12, 255-271.

738 (106)Jalilehvand, F.; Leung, B. O.; Izadifard, M.; Damian, E., Mercury(II) cysteine complexes in 739 alkaline aqueous solution. Inorg. Chem. 2006, 45, 66-73.

740 (107) George, G. N.; Pickering, I. J.; Prince, R. C.; Zhou, Z. H.; Adams, M. W. W., X-ray absorption 741 spectroscopy of Pyrococcus furiosus rubredoxin. J. Biol. Inorg. Chem. 1996, 1, 226-230.

742 (108)Faller, P.; Ctortecka, B.; Troger, W.; Butz, T.; Vasak, M., Optical and TDPAC spectroscopy of $743 \mathrm{Hg}(\mathrm{II})-$-rubredoxin: model for a mononuclear tetrahedral $\mathrm{Hg}(\mathrm{CysS})_{4}{ }^{2-}$ center. J. Biol. Inorg. Chem. $744 \quad 2000,5,393-401$.

745 (109) Maher, M.; Cross, M.; Wilce, M. C. J.; Guss, J. M.; Wedd, A. G., Metal-substituted derivatives 746 of the rubredoxin from Clostridium pasteurianum. Acta Cryst. D. 2004, 60, 298-303.

747 (110)Utschig, L. M.; Bryson, J. W.; O'Halloran, T. V., Mercury-199 NMR of the metal receptor site 748 in MerR and its protein-DNA complex. Science 1995, 268, 380-385.

749 (111) Alsina, T.; Clegg, W.; Fraser, K. A.; Sola, J., Homoleptic cyclohexanethiolato complexes of 750 mercury(II). J. Chem. Soc. Dalton Trans. 1992, 8, 1393-1399.

751 (112)Stillman, M. J., Metallothioneins. Coord. Chem. Rev. 1995, 144, 461-511.

752 (113) Rodic, D.; Spasojevic, V.; Bajorek, A.; Onnerud, P., Similarity of structure properties of $\mathrm{Hg}_{1}$ $753 \times \mathrm{Mn}_{\mathrm{x}} \mathrm{S}$ and $\mathrm{Cd}_{1-\mathrm{x}} \mathrm{Mn}_{\mathrm{x}} \mathrm{S}$ (structure properties of $\mathrm{HgMnS}$ and CdMnS). J. Mag. Mag. Mater. 1996, 152, $754 \quad 159-164$.

755 (114)Thomas, S. A.; Gaillard, J. F., Cysteine addition promotes sulfide production and four-fold 756 Hg(II)-S coordination in actively metabolizing Escherichia coli. Environ. Sci. Technol. 2017, 51, $757 \quad 4642-4651$.

758 (115)Thomas, S. A.; Rodby, K. E.; Roth, E. W.; Wu, J.; Gaillard, J. F., Spectroscopic and microscopic 759 evidence of biomediated $\mathrm{HgS}$ species formation from $\mathrm{Hg}(\mathrm{II})$-cysteine complexes: Implications for $760 \mathrm{Hg}(\mathrm{II})$ bioavailability. Environ. Sci. Technol. 2018, 52, 10030-10039. 
761 (116)Fowle, D. A.; Stillman, M. J., Comparison of the structures of the metal-thiolate binding site 762 in Zn(II)-, Cd(II)-, and Hg(II)-metallothioneins using molecular modeling techniques. J. Biomol. 763 Str. Dyn. 1997, 14, 393-406.

764 (117)Demchenko, I. N.; Denlinger, J. D.; Chernyshova, M.; Yu, K. M.; Speaks, D. T.; Olalde-Velasco,

765 P.; Hemmers, O.; Walukiewicz, W.; Derkachova, A.; Lawniczak-Jablonska, K., Full multiple 766 scattering analysis of XANES at the $\mathrm{Cd} L_{3}$ and $\mathrm{O} K$ edges in $\mathrm{CdO}$ films combined with a soft-x-ray 767 emission investigation. Phys. Rev. B 2010, 82, 075107.

768 (118)Ankudinov, A. L.; Rehr, J. J.; Low, J. J.; Bare, S. R., Sensitivity of Pt x-ray absorption near edge 769 structure to the morphology of small Pt clusters. J. Chem. Phys. 2002, 116, 1911-1919.

770 (119)Glendening, E. D.; Landis, C. R.; Weinhold, F., NBO 6.0: Natural bond orbital analysis 771 program. J. Comput. Chem. 2013, 34, 1429-1437

772

773

\section{LEGENDS TO FIGURES}

774

Figure 1. (a) Mercury L3-edge HR-XANES spectra of the initial aged Hg-DOM (28 $\mu \mathrm{g} \mathrm{Hg/g} \mathrm{DOMi,}$

775 purple) and the final Hg-DOM from aquaria with fish after eight weeks ( $2 \mu \mathrm{g} \mathrm{Hg} / \mathrm{g}$ DOM, blue). (b) Comparison of the final Hg-DOM spectrum with spectra from $\mathrm{Hg}$ linearly complexed to thiol ligands from the humic acid fraction of the DOM (Hg(SR) 2 complex ${ }^{36}$ ) (green) and from nanoparticulate $\beta$-HgS (metacinnabar) (black). The $\mathrm{Hg}(\mathrm{SR})_{2}$ reference was obtained by reacting $\mathrm{Hg}\left(\mathrm{NO}_{3}\right)_{2}$ with the Carex peat $\mathrm{HA}$ isolate for $15 \mathrm{~h}$ to minimize formation of nanoparticulate $\beta$ $\mathrm{HgS}^{37}$, and $\beta-\mathrm{HgS}_{\mathrm{NP}}$ was synthesized at room temperature (RT) from Hg-(L-Cys-OEt)2 complex aged for 80 days in contact with air. ${ }^{37}$ The increase in proportion of $\mathrm{Hg}(\mathrm{SR})_{2}$ is detected in plots (a) and (b) by an increase of the near-edge peak at $12279.5 \mathrm{eV}$, a direct indicator of $\mathrm{Hg}$ (II) linearly coordinated to two thiol ligands, 36,37 and a shift to higher energy of the trailing edge of the spectrum (arrows in (a)). Tetrahedral bonding of mercury to four sulfur atoms in $\beta$-HgS $S_{N P}$ is seen as a shoulder instead of a peak on the rising part of the spectrum. (c) Linear least-squares fit (orange) to the $\mathrm{Hg}-\mathrm{DOM}_{\mathrm{f}}$ spectrum (blue) with $63 \pm 10 \% \mathrm{Hg}(\mathrm{SR})_{2}$ and $37 \pm 10 \%$ nanoparticulate $\beta$-HgS. The normalized sum-squared residual $(N S S)$ is the normalized difference between two spectra expressed as $\Sigma\left[\left(\mathrm{y}_{\exp }-\mathrm{y}_{\mathrm{fit}}\right)^{2}\right] / \Sigma\left(\mathrm{y}_{\exp }{ }^{2}\right)$. Top, ball-and-stick representation of the Hg-thiolate complex and polyhedral representation of the $\beta$-HgS structure.

Figure 2. (a) Mercury L3-edge HR-XANES spectrum of fish (Fish-DOM) exposed to Hg-DOMi = 
793 to $\mathrm{DOM}_{\mathrm{i}}-1453$, dietary $\mathrm{MeHg}$, and $\mathrm{HgCl}_{2}(8 \mu \mathrm{g} / \mathrm{L})$. The Fish-MeHg spectrum has an intense near794 edge peak at $12279.8 \mathrm{eV}$ and the Fish-Hg spectrum has a weak peak, more like $\beta-\mathrm{HgS} \mathrm{SP}_{\mathrm{NP}}$ (Figure 795 1b). (c) Linear least-squares fit (orange) to the Fish-DOM spectrum (green) with a mixture of the

796 Fish-MeHg and Fish-Hg spectra shows that $\mathrm{Hg}$ has a unique chemical form in the fish exposed to 797 the Hg-DOM.

Figure 3. Mercury coordination in fish contaminated by Hg-DOM (DOMi-1453) derived from Hg L3-edge HR-XANES. (a) A one-component fit to all reference spectra identified the dithiolate complexes $\mathrm{Hg}(\mathrm{GSH})_{2}$ and $\left(\mathrm{Hg}(\mathrm{Cys})_{2}\right)$ at physiological $\mathrm{pH}$ as the closest model compounds to the 802 binding environment of $\mathrm{Hg}$ in fish $\left(\mathrm{Hg}\left[(\mathrm{SR})_{2}+(\mathrm{N} / \mathrm{O})_{1-2}\right]\right.$ coordination, Figures $4 \mathrm{a}$ and S9). (b) A 803 two-component fit further identified the tetrathiolate complex $\mathrm{Hg}(\mathrm{Cys})_{4}$ as secondary model 804 species. (c) Fitting residuals were used to evaluate the magnitude of the resultant uncertainty of 805 the determined $\mathrm{Hg}$ coordinations. The residual of the $\mathrm{Hg}(\mathrm{Cys})_{2}+\mathrm{Hg}(\mathrm{Cys})_{4}$ reconstruction is close 806 to experimental noise and has a smaller NSS value than the $\mathrm{Hg}(\mathrm{GSH})_{2}+\mathrm{Hg}(\mathrm{Cys})_{4}$ reconstruction $807\left(1.06 \times 10^{-4}\right.$ vs $\left.1.28 \times 10^{-4}\right)$.

Figure 4. (a) Geometry-optimized model of the molecular structure of the $\mathrm{Hg}(\mathrm{GSH})_{2}$ complex 810 (Video S1). $\mathrm{Hg}(\mathrm{II})$ is bridged to two primary SR- thiolate ligands (one from each GSH molecule) 811 and two secondary 0 ligands from the same GSH molecule forming an intramolecular double-ring 812 chelate. The $\mathrm{Hg}(\mathrm{GSH})_{2}$ complex is further stabilized by an extended intermolecular H-bond 813 network involving the protonated amino groups $\left(-\mathrm{NH}_{3}+\right)$ and deprotonated carboxyl groups of the 814 two glutamate residues. The two H-bridged peptides form a molecular scaffold which binds Hg(II) 815 in a pseudo claw-setting environment. (b) Geometry-optimized $\mathrm{Hg}_{3}(\mathrm{SMe})_{9}$ and $\mathrm{Hg}_{4}(\mathrm{SMe})_{11}$ 816 clusters featuring the inorganic core structure of the $\mathrm{Hg}-\beta$ and $\mathrm{Hg}-\alpha$ domains in vertebrate 817 metallothionein. (c) $\left\{\mathrm{Hg}_{3} \mathrm{~S}_{9}\right\}$ and $\left\{\mathrm{Hg}_{4} \mathrm{~S}_{10}\right\}^{95}, 119$ motifs of the $\beta$ - $\mathrm{HgS}$ structure ${ }^{113}$ showing the 818 similarity of the polyhedral associations with the metallothionein clusters. See Ref. ${ }^{48}$ for details. 819 MP2/TZVP-ecp optimization. Bond lengths, in angstroms, and bond angles are in black. Atomic 820 charges, in units of elementary charge e and calculated by natural population analysis (NPA ${ }^{95,119}$ ), 821 are in blue. Dark red, Hg; yellow, S; blue, N; red, O; gray, C; light gray, H. Cartesian coordinates of 822 the $\mathrm{Hg}(\mathrm{GSH})_{2}$ model are provided in the SI. 
TABLE 1. Samples codes and concentration of $\mathrm{Hg}$ in the initial and final $\mathrm{Hg}(\mathrm{II})$-spiked DOM and in fish

\begin{tabular}{|c|c|c|c|c|c|c|c|}
\hline Experimenta & $\begin{array}{c}\text { Initial Hgb } \\
{[\mu \mathrm{g} / \mathrm{g} \text { DOM] }}\end{array}$ & $\begin{array}{c}\text { Initial Hgc } \\
\text { in water } \\
{[\mu \mathrm{g} / \mathrm{L}]}\end{array}$ & $\begin{array}{c}\text { Final Hgb } \\
{[\mu \mathrm{g} / \mathrm{g} \text { DOM] }}\end{array}$ & $\begin{array}{c}\text { Final DOM } \\
\text { sample code }\end{array}$ & $\begin{array}{l}{[\mathrm{Hg}] \text { in water }} \\
(\mu \mathrm{g} / \mathrm{L}) \text { at t8 }\end{array}$ & $\begin{array}{l}\text { Whole fish } \mathrm{Hg}^{\mathrm{d}} \\
{[\mu \mathrm{g} / \mathrm{g}] \text { at } \mathrm{t}_{8}}\end{array}$ & $\begin{array}{l}\text { Fraction of } \mathrm{Hg} \text { in } \\
\text { fish at } \mathrm{t}_{8}[\%]^{\mathrm{e}}\end{array}$ \\
\hline $\mathrm{DOM}_{\mathrm{i}}-28$ & $28 \pm 3$ & $3 \pm 6$ & $2 \pm 1$ & $\mathrm{DOM}_{\mathrm{f}}-2$ & $1.3 \pm 0.3$ & $0.33 \pm 0.03$ & $1.9 \pm 0.4$ \\
\hline $\mathrm{DOM}_{\mathrm{i}}-270$ & $270 \pm 3$ & $31 \pm 5$ & $27 \pm 1$ & $\mathrm{DOM}_{\mathrm{f}}-27$ & $11.5 \pm 0.5$ & $1.06 \pm 0.08$ & $0.88 \pm 0.07$ \\
\hline $\mathrm{DOM}_{\mathrm{i}}-1453$ & $1453 \pm 8$ & $124 \pm 6$ & $240 \pm 1$ & $\mathrm{DOM}_{\mathrm{f}}-240$ & $70 \pm 2.8$ & $2.20 \pm 0.14$ & $0.32 \pm 0.02$ \\
\hline $\mathrm{HgCl}_{2}\left(\mathrm{C}_{\mathrm{Hg}}\right)$ & & $5.2 \pm 0.6$ & & & $1.1 \pm 0.2$ & $10.4 \pm 0.3$ & $50 \pm 9$ \\
\hline
\end{tabular}

${ }^{a}$ Values represent averages from duplicate experimental aquaria. ${ }^{b}$ Concentrations measured on freeze-dried DOM. ${ }^{c}$ Concentration of $\mathrm{Hg}$ in unfiltered water. ${ }^{d}$ Concentration based on dry weight. ${ }^{e}$ Calculation performed by dividing the total amount of accumulated Hg in whole fish by the total amount of $\mathrm{Hg}$ present in the aquaria $(35 \mathrm{~L})$, both at $\mathrm{t}_{8}$. The first quantity was obtained by multiplying the total number of fish at $\mathrm{t}_{8}(n=46)$ by the corrected concentration of $\mathrm{Hg}$ in whole fish at $\mathrm{t}_{8}$ and the average dry fish weight of $80.5 \pm 20 \mathrm{mg}$. The corrected

concentration of $\mathrm{Hg}$ in whole fish at $\mathrm{t}_{8}$ is the concentration accumulated between $\mathrm{t}_{0}$ and $\mathrm{t}_{8}$ and therefore calculated by subtracting from the whole fish $\mathrm{Hg}$ concentration at $\mathrm{t}_{8}$ that of control fish at $\mathrm{t}_{0}$ equal to $0.09 \pm 0.03 \mu \mathrm{g} / \mathrm{g}$ dry weight. 

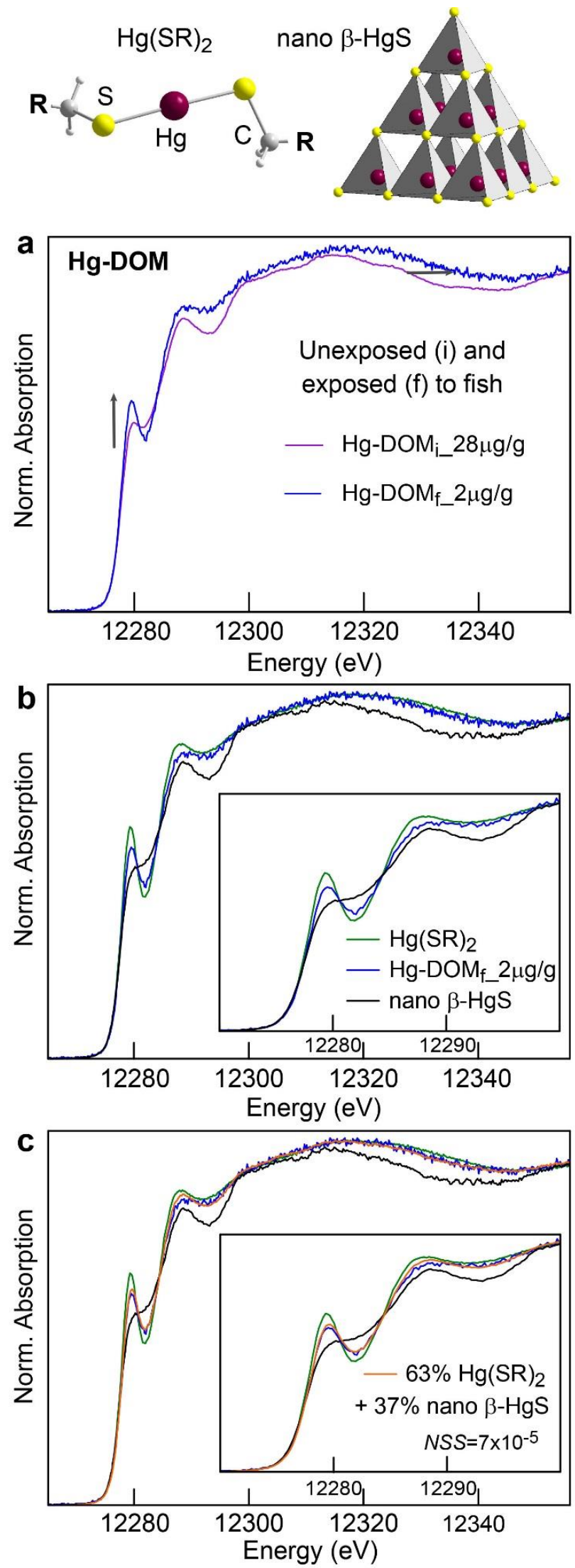

Figure 1

Please, print to fit the full width of one column, thank you 

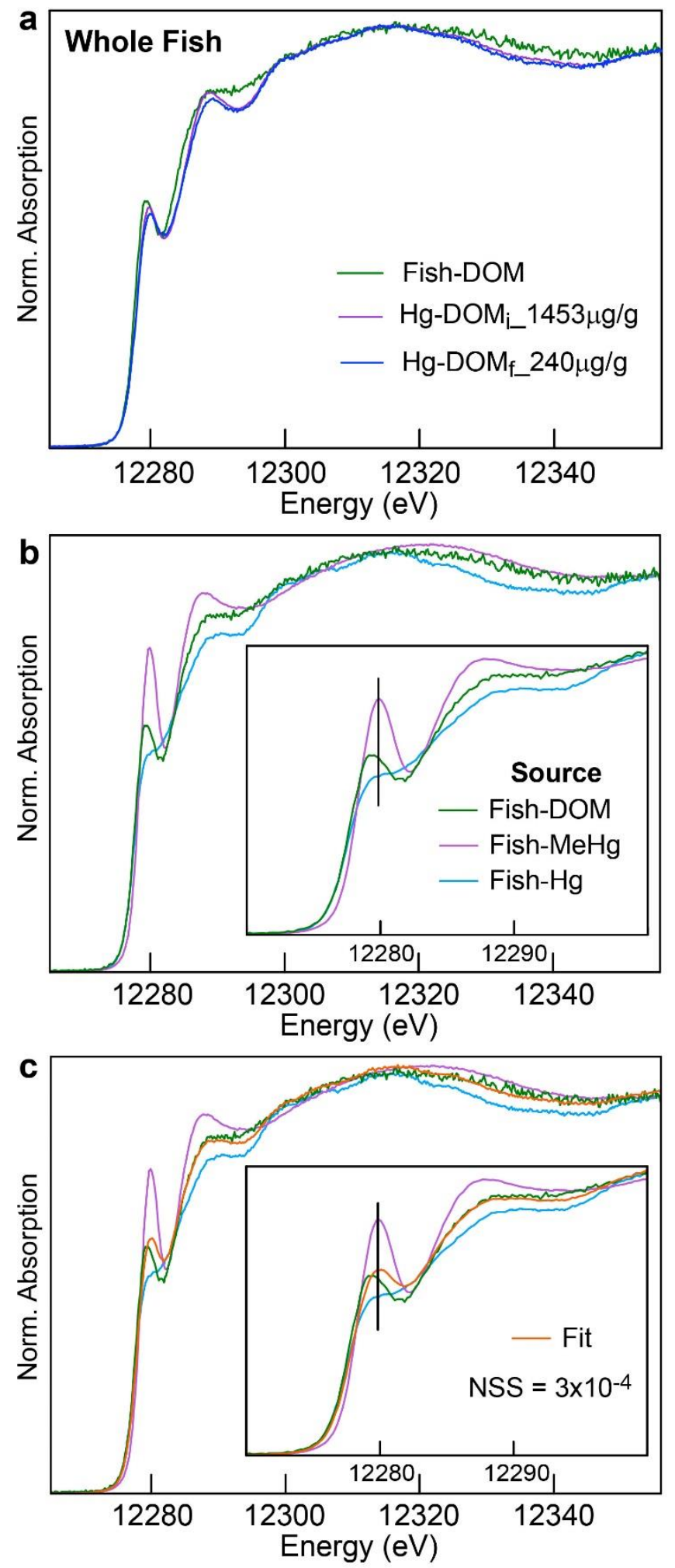

Figure 2

Please, print to fit the full width of one column, thank you 

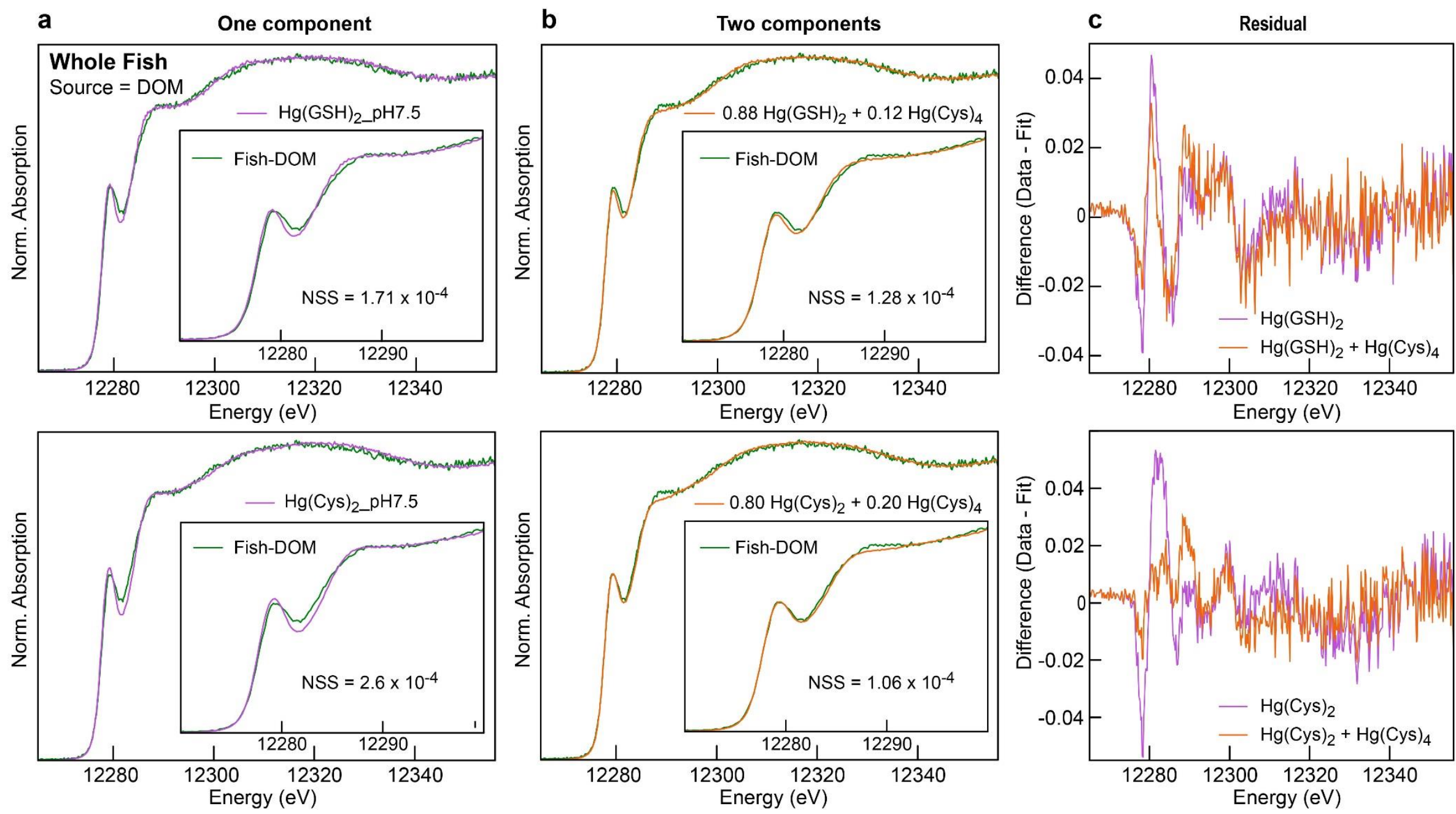

Figure 3

Please, print to fit the full width of two columns, thank you 


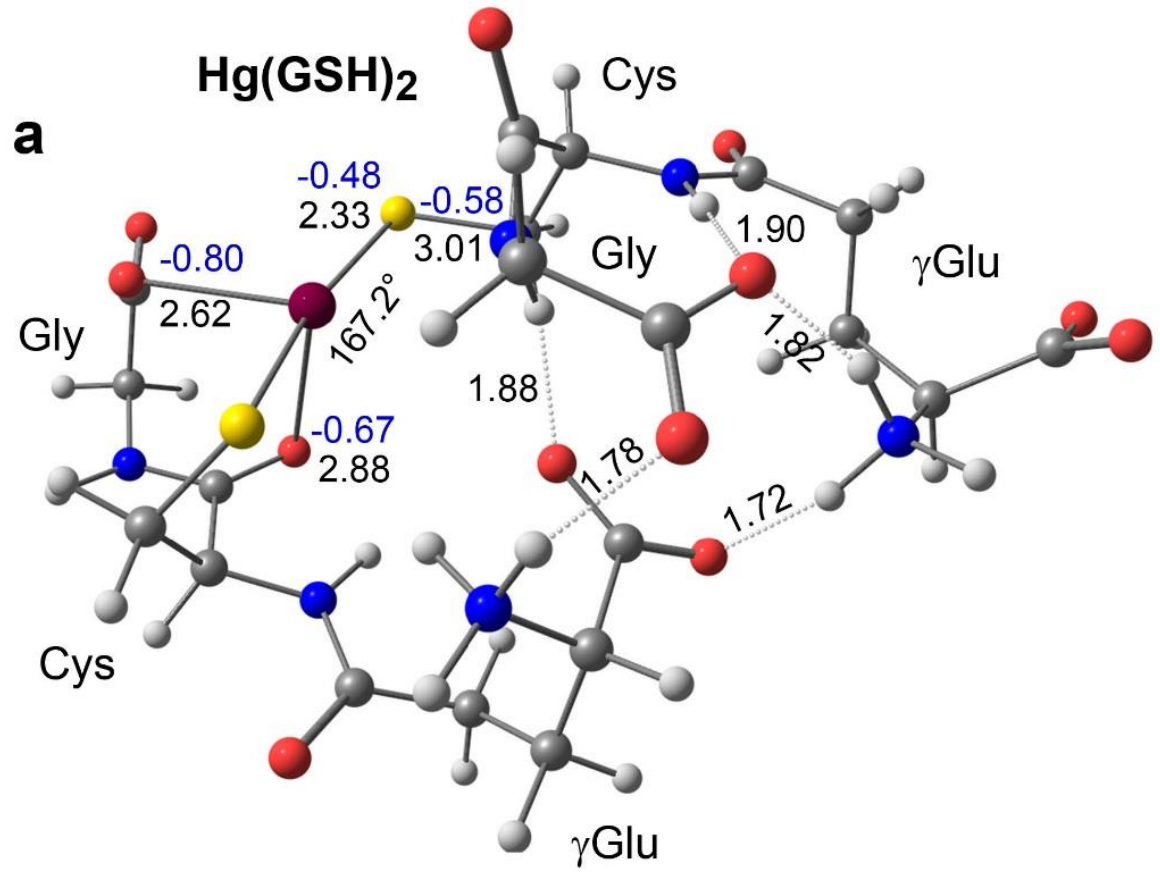

b $\mathrm{Hg}_{3} \mathrm{~S}_{9} \beta$ domain

$\mathrm{Hg}_{4} \mathrm{~S}_{11} \alpha$ domain
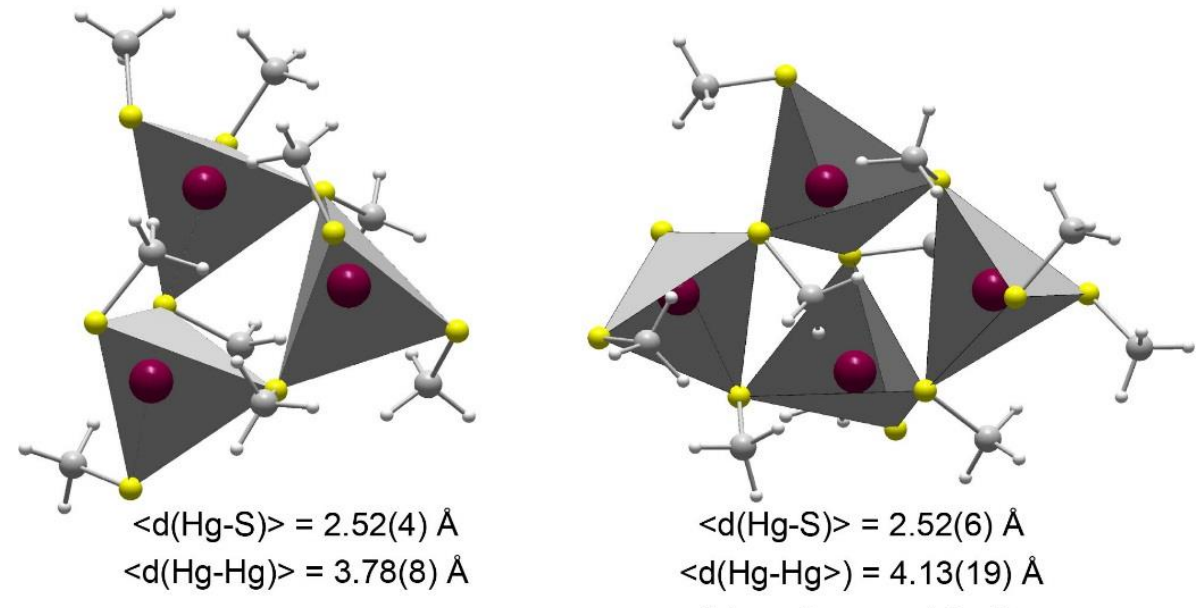

C $\quad \mathrm{Hg}_{3} \mathrm{~S}_{9} \beta-\mathrm{HgS}$

$\mathrm{Hg}_{4} \mathbf{S}_{10} \beta-\mathrm{HgS}$
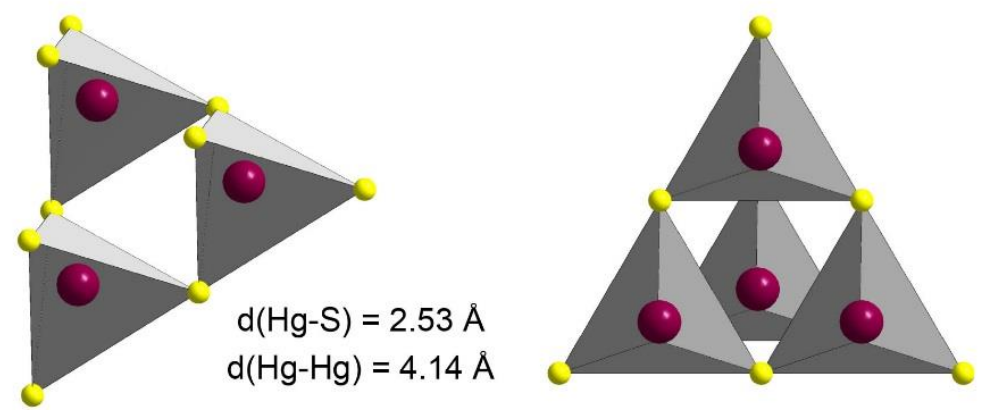

Figure 4

Please, print to fit the full width of one column, thank you 